\title{
Coral calcifying fluid aragonite saturation states derived from Raman spectroscopy
}

\author{
Thomas M. DeCarlo ${ }^{1,2}$, Juan P. D’Olivo ${ }^{1,2}$, Taryn Foster ${ }^{3}$, Michael Holcomb ${ }^{1,2}$, Thomas Becker ${ }^{4,5}$, and \\ Malcolm T. McCulloch ${ }^{1,2}$ \\ ${ }^{1}$ Oceans Institute and School of Earth Sciences, The University of Western Australia, \\ 35 Stirling Hwy, Crawley 6009, Australia \\ ${ }^{2}$ ARC Centre of Excellence for Coral Reef Studies, The University of Western Australia, \\ 35 Stirling Hwy, Crawley 6009, Australia \\ ${ }^{3}$ Australian Institute of Marine Science, Crawley 6009, Australia \\ ${ }^{4}$ Centre for Microscopy, Characterisation and Analysis, The University of Western Australia, Crawley 6009, Australia \\ ${ }^{5}$ Department of Chemistry, Curtin Institute of Functional Molecules and Interfaces, \\ Curtin University, GPO Box U1987, Perth 6845, Australia
}

Correspondence to: Thomas M. DeCarlo (thomas.decarlo@uwa.edu.au)

Received: 17 May 2017 - Discussion started: 29 June 2017

Revised: 17 October 2017 - Accepted: 23 October 2017 - Published: 24 November 2017

\begin{abstract}
Quantifying the saturation state of aragonite $\left(\Omega_{\mathrm{Ar}}\right)$ within the calcifying fluid of corals is critical for understanding their biomineralization process and sensitivity to environmental changes including ocean acidification. Recent advances in microscopy, microprobes, and isotope geochemistry enable the determination of calcifying fluid $\mathrm{pH}$ and $\left[\mathrm{CO}_{3}^{2-}\right]$, but direct quantification of $\Omega_{\mathrm{Ar}}$ (where $\left.\Omega_{\mathrm{Ar}}=\left[\mathrm{CO}_{3}^{2-}\right]\left[\mathrm{Ca}^{2+}\right] / K_{\mathrm{sp}}\right)$ has proved elusive. Here we test a new technique for deriving $\Omega_{\text {Ar }}$ based on Raman spectroscopy. First, we analysed abiogenic aragonite crystals precipitated under a range of $\Omega_{\mathrm{Ar}}$ from 10 to 34, and we found a strong dependence of Raman peak width on $\Omega_{\mathrm{Ar}}$ with no significant effects of other factors including $\mathrm{pH}, \mathrm{Mg} / \mathrm{Ca}$ partitioning, and temperature. Validation of our Raman technique for corals is difficult because there are presently no direct measurements of calcifying fluid $\Omega_{\mathrm{Ar}}$ available for comparison. However, Raman analysis of the international coral standard JCp-1 produced $\Omega_{\text {Ar }}$ of $12.3 \pm 0.3$, which we demonstrate is consistent with published skeletal $\mathrm{Mg} / \mathrm{Ca}, \mathrm{Sr} / \mathrm{Ca}$, $\mathrm{B} / \mathrm{Ca}, \delta^{11} \mathrm{~B}$, and $\delta^{44} \mathrm{Ca}$ data. Raman measurements are rapid ( $\leq 1 \mathrm{~s})$, high-resolution $(\leq 1 \mu \mathrm{m})$, precise (derived $\Omega_{\mathrm{Ar}} \pm 1$ to 2 per spectrum depending on instrument configuration), accurate $\left( \pm 2\right.$ if $\Omega_{\mathrm{Ar}}<20$ ), and require minimal sample preparation, making the technique well suited for testing the sensitivity of coral calcifying fluid $\Omega_{\mathrm{Ar}}$ to ocean acidification and
\end{abstract}

warming using samples from natural and laboratory settings. To demonstrate this, we also show a high-resolution time series of $\Omega_{\mathrm{Ar}}$ over multiple years of growth in a Porites skeleton from the Great Barrier Reef, and we evaluate the response of $\Omega_{\text {Ar }}$ in juvenile Acropora cultured under elevated $\mathrm{CO}_{2}$ and temperature.

\section{Introduction}

The calcium carbonate $\left(\mathrm{CaCO}_{3}\right)$ skeletons built by coral polyps are the building blocks of massive coral reef structures that protect shorelines, bolster tourism, and host some of the greatest concentrations of biodiversity on the planet (Knowlton et al., 2010; Costanza et al., 2014). Critical to the coral calcification process is the extraction of $\mathrm{Ca}^{2+}$ and $\mathrm{CO}_{3}^{2-}$ ions from seawater to grow aragonitic $\mathrm{CaCO}_{3}$ crystals. But corals today live in seawater that is less conducive to $\mathrm{CaCO}_{3}$ nucleation than it was just a century ago. In surface waters of the tropical oceans, carbonate ion concentrations ( $\left[\mathrm{CO}_{3}^{2-}\right]$ ) have declined by $\sim 15 \%$ since 1900 due to invasion of anthropogenic $\mathrm{CO}_{2}$, which dissociates into carbonic acid and decreases seawater $\mathrm{pH}$ and $\left[\mathrm{CO}_{3}^{2-}\right]$ through a process referred to as ocean acidification (Caldeira and Wickett, 2003; Doney et al., 2009). If anthropogenic $\mathrm{CO}_{2}$ emis- 
sions continue unabated, by the end of the 21 st century the $\left[\mathrm{CO}_{3}^{2-}\right]$ of surface seawater is projected to decline to $\sim 50 \%$ of pre-industrial levels (Hoegh-Guldberg et al., 2014). This rapid change in ocean carbonate chemistry, likely unprecedented for hundreds of millions of years (Hönisch et al., 2012; Zeebe et al., 2016), has sparked concerns for coral growth. Indeed, laboratory experiments repeatedly demonstrate that coral calcification rates decrease in response to lower $\left[\mathrm{CO}_{3}^{2-}\right]$ or $\left[\mathrm{Ca}^{2+}\right]$ (Gattuso et al., 1998; Chan and Connolly, 2013; Comeau et al., 2017), leading to projections that as $\mathrm{CO}_{2}$ levels continue to rise calcification will decline to unsustainable levels, such that there is net reef erosion (HoeghGuldberg et al., 2007; Pandolfi et al., 2011).

Yet signs of resilience do exist. Some coral species are able to maintain normal calcification rates across large natural acidification gradients (Fabricius et al., 2011; Shamberger et al., 2014; Barkley et al., 2015), indicative of adaptation or acclimation (Barkley et al., 2017). One potential mechanism to counteract acidification of surrounding seawater is $\mathrm{pH}$ homeostasis at the site of calcification (Georgiou et al., 2015; Barkley et al., 2017). Corals calcify from an isolated fluid located between the living tissue and the existing skeleton (Barnes, 1970; Cohen and McConnaughey, 2003; Venn et al., 2011; Tambutté et al., 2012). Up-regulation of pH within this fluid, potentially achieved via proton pumping and/or symbiont photosynthesis, elevates the saturation state with respect to aragonite $\left(\Omega_{\mathrm{Ar}}\right)$, contributing to rapid nucleation and growth of aragonite crystals (Gattuso et al., 1999; Cohen and McConnaughey, 2003; Al-Horani et al., 2003; McCulloch et al., 2012; Kubota et al., 2015).

Characterizing the $\Omega_{\mathrm{Ar}}$ of the calcifying fluid, and understanding its sensitivities to variations in the reef environment, is therefore essential for accurately forecasting coral calcification responses to 21 st century ocean acidification. $\mathrm{Ob}$ serving this fluid has proved difficult though, due to its small size and isolation beneath the living polyp (Clode and Marshall, 2002). Estimates of fluid carbonate chemistry have so far been derived from micro-electrodes, $\mathrm{pH}$-sensitive dyes, boron isotopes, $\mathrm{B} / \mathrm{Ca}, \mathrm{U} / \mathrm{Ca}$, and bulk calcification rates (AlHorani et al., 2003; Trotter et al., 2011; Venn et al., 2011; DeCarlo et al., 2015; Cai et al., 2016; Holcomb et al., 2016; Raybaud et al., 2017). However, these approaches do not always agree (Ries, 2011; Holcomb et al., 2014), and they have so far focused on calcifying fluid carbonate chemistry without considering the effect of $\left[\mathrm{Ca}^{2+}\right]$ on $\Omega_{\mathrm{Ar}}$.

A potential alternative approach to quantify calcifying fluid $\Omega_{\mathrm{Ar}}$ is based on the Raman scattering from a laser focused onto the skeleton. When light interacts with a material, a small percentage (typically $<0.0001 \%$ ) of the photons are scattered inelastically (referred to as Raman or Stokes scattering), resulting in a change of energy and frequency (Smith and Dent, 2005). The frequency shifts associated with Raman scattering are characteristic of both the internal vibrations of a molecule and the lattice vibrations between molecules in a crystal, which makes Raman spectroscopy a valuable tool for mineral identification (Urmos et al., 1991; Dandeu et al., 2006; Brahmi et al., 2010; Clode et al., 2011; Nehrke et al., 2011; Stock et al., 2012; Foster and Clode, 2016; Stolarski et al., 2016; Roger et al., 2017). Importantly, Raman peaks can also provide information regarding the chemical composition of crystals and the conditions of the fluid from which they formed. For example, in abiogenic $\mathrm{CaCO}_{3}$, the shapes and positions of the $v_{1}$ peak at $\sim 1085 \mathrm{~cm}^{-1}$ (which represents symmetric stretching of the carbonate $\mathrm{C}-\mathrm{O}$ bond) have been correlated with $\mathrm{Mg}$ content and/or crystallinity (Bischoff et al., 1985; Wang et al., 2012; Perrin et al., 2016). A highly crystalline $\mathrm{CaCO}_{3}$ with relatively few defects or impurities will have a narrow $v_{1}$ peak because the $\mathrm{C}-\mathrm{O}$ bonds throughout the crystals are of the same, or very similar, length (Bischoff et al., 1985). Defects in the crystals and/or trace element impurities cause positional disorder of $\mathrm{CO}_{3}$ in the lattice. Positional disorder affects the length, and thus the strength and vibrational frequency, of $\mathrm{C}-\mathrm{O}$ bonds (Bischoff et al., 1985). An increase in disorder leads to an increase in the distribution of $\mathrm{C}-\mathrm{O}$ bond lengths, causing an increase in $v_{1}$ peak width (Bischoff et al., 1985; Addadi et al., 2003; Lin et al., 2007; Wang et al., 2012; McElderry et al., 2013; Perrin et al., 2016).

In biogenic calcium carbonates, correlations have been reported between $v_{1}$ peak widths and environmental conditions, including temperature and seawater $p \mathrm{CO}_{2}$ (Kamenos et al., 2013, 2016; Hennige et al., 2015; Pauly et al., 2015). These changes potentially reflect differences in calcifying fluid carbonate chemistry. Crystals growing from more supersaturated solutions generally have more defects and incorporate more impurities (Watson, 2004), resulting in relatively disordered crystal lattices and wide Raman peaks (Urmos et al., 1991). This hypothesis is generally consistent with empirical observations of biogenic calcium carbonates, in which $v_{1}$ peak widths increase as ambient seawater $p \mathrm{CO}_{2}$ decreases and/or pH increases (i.e. higher $\Omega_{\mathrm{Ar}}$ ) (Kamenos et al., 2013; Hennige et al., 2015; Pauly et al., 2015). However, corals exert strong control on the carbonate chemistry of their calcifying fluid by elevating $\mathrm{pH}$ and/or $\Omega_{\mathrm{Ar}}$ at the site of calcification to facilitate more rapid crystal growth (Al-Horani et al., 2003; Venn et al., 2011; McCulloch et al., 2012). Thus, the observed correlations between Raman peak widths and ambient seawater conditions likely do not reflect the true sensitivity of aragonite Raman peaks to seawater chemistry, but rather the sensitivity of calcifying fluid chemistry to external $\mathrm{pH}$ and/or $\Omega_{\mathrm{Ar}}$. For this reason, information regarding the relationship between carbonate chemistry and Raman peak width in abiogenic experiments is required to quantitatively interpret Raman spectra of biogenic $\mathrm{CaCO}_{3}$ with respect to the actual calcifying fluid conditions.

Here, we first evaluate the controls on Raman $v_{1}$ peak width using abiogenically precipitated aragonites. These samples allow us to test the sensitivities of $v_{1}$ peak width against geochemical composition (e.g. $\mathrm{Mg} / \mathrm{Ca}$ ) and fluid conditions (including $\Omega_{\mathrm{Ar}}, \mathrm{pH}$, and temperature) directly, 
without the confounding influence of a coral polyp. We derive a calibration between $\nu_{1}$ peak width and $\Omega_{\mathrm{Ar}}$, and apply it to estimate $\Omega_{\mathrm{Ar}}$ of the international coral skeleton standard $\mathrm{JCp}-1$, for which independent lines of geochemical evidence allow us to test the accuracy of our approach. Finally, we demonstrate the applicability of Raman spectroscopy by (1) reconstructing multiple years of $\Omega_{\mathrm{Ar}}$ variability in a Porites coral collected from the Great Barrier Reef (GBR) (D'Olivo and McCulloch, 2017), and (2) comparing $\Omega_{\mathrm{Ar}}$ in cultured juvenile Acropora spicifera exposed to elevated $\mathrm{CO}_{2}$ and temperature treatments (Foster et al., 2015).

\section{Methods}

\subsection{Raman measurements}

Raman spectroscopy was used to analyse the abiogenic aragonite precipitates described in DeCarlo et al. (2015) and Holcomb et al. (2016) (Supplement Table S1). Briefly, aragonite was precipitated by addition of $\mathrm{Na}_{2} \mathrm{CO}_{3}$ and $\mathrm{NaHCO}_{3}$ solutions to seawater. Various $\mathrm{Na}_{2} \mathrm{CO}_{3} / \mathrm{NaHCO}_{3}$ ratios and pumping rates produced a range of $\Omega_{\mathrm{Ar}}$ from 10 to 34 while achieving some independence between $\Omega_{\mathrm{Ar}}$ and other carbonate system variables (e.g. $r^{2}$ between $\Omega_{\mathrm{Ar}}$ and $\mathrm{pH}$ was only 0.34 ). Most (22 of 28) experiments were conducted at $25.5^{\circ} \mathrm{C}$, but two experiments were conducted each at 20,33 , and $40^{\circ} \mathrm{C}$. Two experiments (f08 and g13) were conducted from seawater with $\left[\mathrm{Ca}^{2+}\right]$ elevated by addition of dissolved $\mathrm{CaCO}_{3}$.

Raman spectra of the abiogenic aragonites were originally reported in DeCarlo et al. (2015) and Holcomb et al. (2016). These initial spectra were collected at Woods Hole Oceanographic Institution (WHOI) with a Horiba LabRam HR800 Raman spectrometer using a $785 \mathrm{~nm}$ laser source, $40 \times$ objective, $600 \mathrm{~mm}^{-1}$ grating, and CCD detector maintained at $-70^{\circ} \mathrm{C}$. Spectral resolution was approximately $1.2 \mathrm{~cm}^{-1}$. Three grains were analysed per experiment with an integration time of $5 \mathrm{~s}$ per spectrum. Subsequently, we repeated analyses of a subset of these aragonites (samples f02, f03, f06, g07, g13, h09) at the Centre for Microscopy, Characterisation, and Analysis (CMCA) at the University of Western Australia. These more refined measurements, which are the basis of this study, were performed with a WITec Alpha300 RA+ confocal Raman microscope using a $785 \mathrm{~nm}$ laser source, $20 \times$ objective with numerical aperture of 0.5 , $1200 \mathrm{~mm}^{-1}$ grating, and an Andor iDUS $401 \mathrm{CCD}$ detector maintained at $-60^{\circ} \mathrm{C}$. The nominal spectral resolution was $1.3 \mathrm{~cm}^{-1}$. A silicon chip was analysed to facilitate comparison of peak position with other laboratories (the strong $\mathrm{Si}$ peak was present at $522.9 \mathrm{~cm}^{-1}$ ). For analysis of the abiogenic aragonites, at least five grains were analysed per experiment with 5-10 spectra per grain and integration times between 0.1 and $5 \mathrm{~s}$ (see Supplement for a comparison between instruments and discussion of the general applicabil- ity of our results to measurements in other laboratories). All analyses of coral skeletons described below were conducted with the WITec instrument using $1 \mathrm{~s}$ integration times.

The Porites coral skeleton standard JCp-1 (Okai et al., 2002) was analysed to facilitate comparison between Raman results and geochemical estimates of calcifying fluid $\Omega_{\mathrm{Ar}}$ and $\left[\mathrm{Ca}^{2+}\right]$. We collected 440 spectra from various grains spread onto a glass slide. Although JCp-1 exists in ground form, we note that analysis of intact coral skeletons is also possible (Wall and Nehrke, 2012; Hennige et al., 2014) and that peak widths apparently do not depend on whether the sample is powdered or intact (Zakaria et al., 2008), as long as the grain size exceeds the laser spot size.

We also collected Raman spectra down-core in a Porites skeleton collected from the Great Barrier Reef (the sample is described in detail in D'Olivo and McCulloch (2017). Briefly, the core was collected near Havannah Island, an inshore reef in the central GBR where corals bleached during 1998. The skeleton was cut in a slab and cleaned with bleach as described by D'Olivo and McCulloch (2017), but no additional preparation was required. D'Olivo and McCulloch (2017) present $\delta^{11} \mathrm{~B}$ and trace element/Ca ratios from multiple tracks in the skeleton, and they show anomalies to the skeletal geochemistry corresponding to the 1998 thermal stress event. We used the automated microscope stage and area-mapping features of the WITec instrument to measure Raman spectra in a down-core transect at $50 \mu \mathrm{m}$ resolution, covering approximately 6 years of growth from 1996 to 2002 . The TrueSurface module was used to construct a topography map of the skeleton that was then followed by the instrument to ensure the sample was always in-focus for the Raman measurements. A maximum depth of $1 \mathrm{~mm}$ below the cut surface was set to limit the integration of signal from skeleton of different ages. Each time point represents the average of 10 spectra spaced horizontally in $100 \mu \mathrm{m}$ increments.

Finally, we analysed skeletons of the cultured juvenile Acropora described in Foster et al. (2015, 2016). Briefly, larval planulae were maintained in "Control" $\left(24^{\circ} \mathrm{C}, 250\right.$

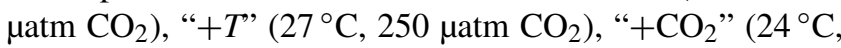
$900 \mu$ atm $\left.\mathrm{CO}_{2}\right)$, and " $+\mathrm{CO}_{2}+T^{\prime}$ " $\left(27^{\circ} \mathrm{C}, 900 \mu\right.$ atm $\left.\mathrm{CO}_{2}\right)$ treatments. Raman data were previously reported for these corals in Foster and Clode (2016), but those earlier measurements were conducted with a $600 \mathrm{~mm}^{-1}$ grating, which made it difficult to resolve changes in peak width (see Supplement). We therefore collected 25 new Raman spectra from each of three broken skeletal pieces from each of three corals, per treatment. The TrueSurface module was used to ensure all measurements were taken with the optics well focused on the samples.

\subsection{Calculations and statistics}

For all Raman spectra, we utilized the FWHM (full width at half maximum) intensity of the $v_{1}$ peak (Fig. 1). A Gaussianshaped curve was fitted to each spectrum between 1080 and 


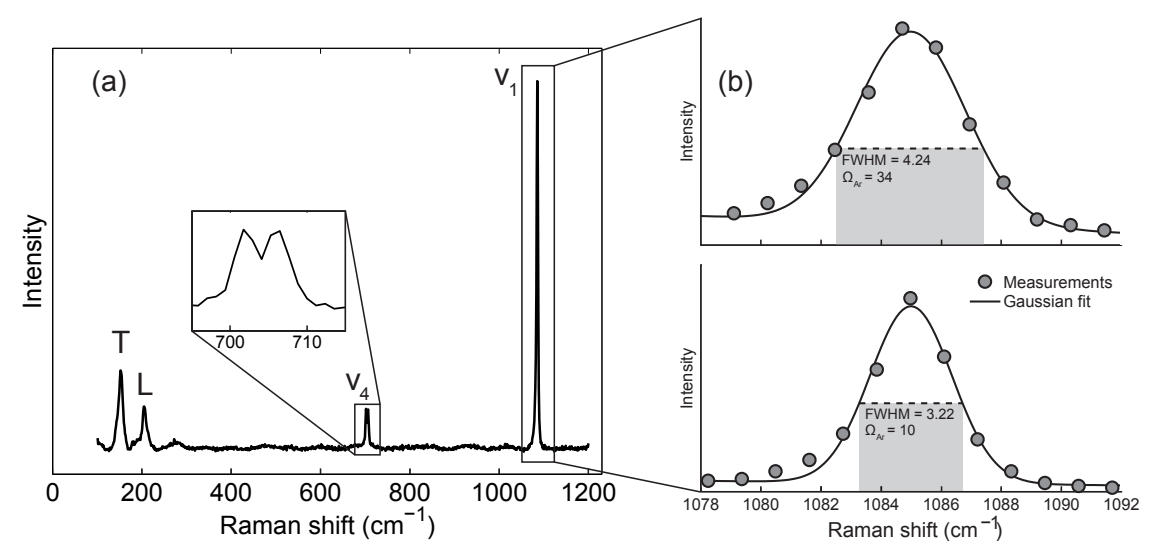

Figure 1. Example Raman spectra and peak width analyses. (a) Raman spectrum of precipitate from experiment f03, with the peaks labelled following White (1974) and Bischoff et al. (1985): T, translation (lattice mode); L, libration (lattice mode); $v_{4}$, in-plane bend (internal mode); $v_{1}$, symmetric stretch (internal mode). This spectrum is readily identifiable as $\mathrm{CaCO}_{3}$, based on the strong $v_{1}$ peak at approximately $1085 \mathrm{~cm}^{-1}$, and distinguished as aragonite rather than other $\mathrm{CaCO}_{3}$ polymorphs (calcite and vaterite) based on the positions of the $\mathrm{T}$, $\mathrm{L}$, and $v_{4}$ peaks (Dandeu et al., 2006). The double peak between $700-710 \mathrm{~cm}^{-1}$ is the feature that most clearly distinguishes aragonite from calcite or vaterite (Urmos et al., 1991). (b) Measurement of $v_{1}$ peak width. The grey points are the measured intensities at the corresponding Raman wavenumber shift. The black lines show the Gaussian curves fit to the data, and the grey boxes indicate the measured peak widths $\left(v_{1}\right.$ FWHM). Note that measured $v_{1}$ FWHM is converted to true $v_{1}$ FWHM for analysis in subsequent figures. The $y$ axis scale is in arbitrary intensity units.

$1100 \mathrm{~cm}^{-1}$ with the following expression:

$y=b+m x+k e^{\frac{-(x-p)^{2}}{2 s^{2}}}$,

where $y$ is the fit, $x$ is the Raman shift between 1080 and $1100 \mathrm{~cm}^{-1}, b$ is the background intensity, $m$ is the background slope, $k$ is the peak height, $p$ is the peak position (i.e. wavenumber), and $s$ is the standard deviation. Peak intensity varies depending on the smoothness of the surface and the focus of the laser. We removed spectra with $v_{1}$ peak height $<30$ intensity units (signal : noise of approximately 5) due to the larger uncertainties associated with curves fit to these spectra. FWHM is calculated following Weisstein (2017):

$\mathrm{FWHM}=2 s \sqrt{2 \ln (2)} \approx 2.3548 s$,

where $s$ is the standard deviation of the Gaussian curve from Eq. (1). Measured Raman peak widths are known to be convolutions of the "true" peak widths and instrument noise (Nasdala et al., 2001; Wang et al., 2012; Váczi, 2014). The effect of instrument noise on Raman peak widths is directly related to the spectral resolution, which must be accounted for when comparing measurements conducted on different instruments (see Supplement). We used the Nasdala et al. (2001) formula to account for the effect of spectral resolution and calculate true FWHM:

$b_{\mathrm{t}}=b_{\mathrm{m}} \sqrt{1-2\left(\frac{r_{\mathrm{s}}}{b_{\mathrm{m}}}\right)^{2}}$,

where $b_{\mathrm{t}}$ is the true peak width, $b_{\mathrm{m}}$ is the measured peak width, and $r_{\mathrm{s}}$ is the spectral resolution.
In the analysis of the abiogenic aragonite, we used the linear model function in R (R Core Team, 2016) to test for relationships between $v_{1}$ FWHM and $\Omega_{\mathrm{Ar}}$, aragonite precipitation rate, aragonite $\mathrm{Mg} / \mathrm{Ca}$, fluid $\left[\mathrm{CO}_{3}^{2-}\right]$, fluid $\mathrm{pH}$, Raman peak height $(k)$, and Raman peak position $(p)$. Since $\Omega_{\text {Ar }}$ was the single variable most strongly correlated with $\nu_{1}$ FWHM, we also evaluated linear models with two explanatory variables: $\Omega_{\mathrm{Ar}}$ and the rest of the variables listed above. Analysis of variance (ANOVA) was used to test whether multivariate models were significantly better than the model based on $\Omega_{\mathrm{Ar}}$ alone. We tested for normality of residuals with Kolmogorov-Smirnov tests and homogeneity of variances with Levene's test.

For the cultured Acropora, we calculated the mean $\Omega_{\text {Ar }}$ of each skeletal fragment using the abiogenic $v_{1}$ FWHM- $\Omega_{\mathrm{Ar}}$ calibration, weighting the 25 measurements per fragment by peak height. We then tested whether the data were significantly different from normal distributions with KolmogorovSmirnov tests and homogeneity of variances was checked with Levene's test. Finding no significant differences from normal distributions and no significant differences in variance among treatments, we conducted a two-way ANOVA and evaluated the effects with Tukey's honest significant difference test. Statistical significance was defined as $p<0.05$.

\subsection{Mg/Ca partitioning between aragonite and seawater}

We also report here the partitioning of $\mathrm{Mg} / \mathrm{Ca}$ between these abiogenic aragonites and seawater because (1) previous studies have suggested that $\mathrm{Mg} / \mathrm{Ca}$ is important for interpret- 
ing Raman peak widths (Bischoff et al., 1985; Urmos et al., 1991), and (2) $\mathrm{Mg} / \mathrm{Ca}$ is used as a constraint in our comparison of JCp-1 geochemistry and Raman spectroscopy. Partitioning of $\mathrm{Mg}^{2+}$ between aragonite and seawater can be described by an exchange for $\mathrm{Ca}^{2+}$ in the aragonite lattice, with a partition coefficient $\left(K_{\mathrm{D}}\right)$ expressed as

$K_{\mathrm{D}}^{\mathrm{Mg} / \mathrm{Ca}}=\frac{\frac{\mathrm{Mg}}{\mathrm{Ca} \text { aragonite }}}{\frac{\mathrm{Mg}}{\mathrm{Ca}} \text { seawater }}$,

where $K_{\mathrm{D}}$ is dimensionless (Kinsman and Holland, 1969; Gaetani and Cohen, 2006). While there is some uncertainty in the mechanism of $\mathrm{Mg}^{2+}$ incorporation into aragonite (Montagna et al., 2014), the $K_{\mathrm{D}}$ nevertheless serves as an empirical measure of the distribution of $\mathrm{Mg} / \mathrm{Ca}$ between aragonite and seawater under various conditions. DeCarlo et al. (2015) reported $K_{\mathrm{D}}$ for $\mathrm{Sr} / \mathrm{Ca}$ from these same samples, and here we follow the same calculations for $K_{\mathrm{D}}^{\mathrm{Mg} / \mathrm{Ca}}$ using the $\mathrm{Mg} / \mathrm{Ca}$ data from Holcomb et al. (2016), except for the slight modifications to the calculations described below. Briefly, $K_{\mathrm{D}}^{\mathrm{Mg} / \mathrm{Ca}}$ was calculated from the measured $\mathrm{Mg} / \mathrm{Ca}$ in the bulk precipitate (Holcomb et al., 2016), estimates of $\mathrm{Mg} / \mathrm{Ca}$ in the initial fluid (seawater), and modelling the evolution of elemental concentrations in the fluid through the course of each experiment. However, since $[\mathrm{Mg}]$ in the initial seawater was not reported, we instead calculated initial $[\mathrm{Mg}]$ and $[\mathrm{Ca}]$ from the established relationships between salinity and concentrations of these elements in seawater (Riley and Tongudai, 1967). Our approach also differs from DeCarlo et al. (2015) in that they combined element/Ca measurements of both the final solution and the bulk solid to calculate $K_{\mathrm{D}}$, whereas we used only the reported aragonite $\mathrm{Mg} / \mathrm{Ca}$ because final fluid $[\mathrm{Mg}]$ was not measured. Two of the experiments (f08 and g13) were conducted with initial elemental concentrations modified from seawater by addition of dissolved $\mathrm{CaCO}_{3}$, and they were excluded from $K_{\mathrm{D}}^{\mathrm{Mg} / \mathrm{Ca}}$ calculations due to uncertainty of the fluid $\mathrm{Mg} / \mathrm{Ca}$ ratio.

\section{Results}

In the abiogenic aragonites analysed in this study, $v_{1}$ FWHM was strongly correlated with seawater $\Omega_{\mathrm{Ar}}\left(r^{2}=0.70, p<\right.$ 0.001; Fig. 2 and Tables 1-2). Aragonite precipitation rate $(G)$ is a function of $\Omega_{\mathrm{Ar}}$ and temperature $(T)$ (Burton and Walter, 1987), and thus the experiments conducted at different $T$ allow us to isolate the influence of $\Omega_{\mathrm{Ar}}$ from $G$. In contrast to the strong dependence of $v_{1}$ FWHM on $\Omega_{\mathrm{Ar}}$, there was no significant correlation between $v_{1}$ FWHM and $G$ (Fig. 3; Table 1). The $v_{1}$ FWHM was significantly correlated with the aragonite $\mathrm{Mg} / \mathrm{Ca}$ ratio, fluid $\left[\mathrm{CO}_{3}^{2-}\right], \mathrm{pH}, T$, and $v_{1}$ peak height (Fig. 3; Table 1). However, these correlations were all weaker than the correlation between $v_{1}$ FWHM and $\Omega_{\mathrm{Ar}}$, and in multivariate models combining $\Omega_{\mathrm{Ar}}$ with either $\mathrm{Mg} / \mathrm{Ca},\left[\mathrm{CO}_{3}^{2-}\right], \mathrm{pH}, T$, or $v_{1}$ peak height, the only sig-

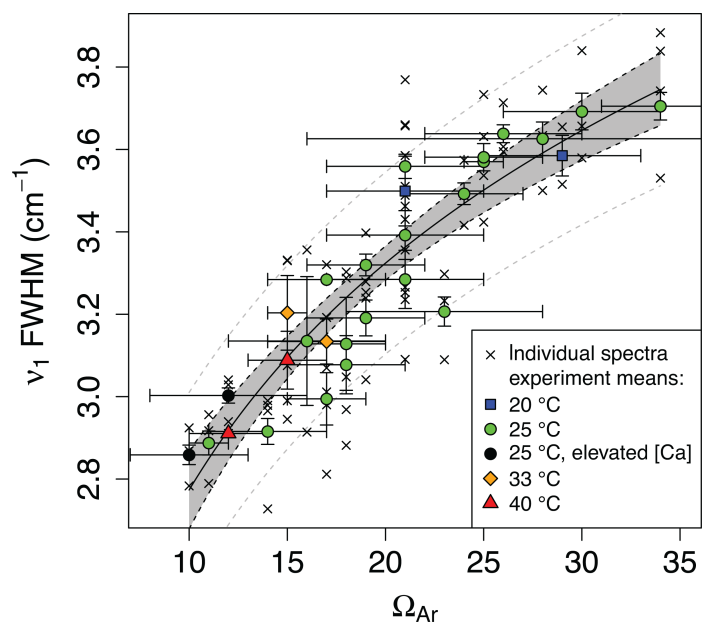

Figure 2. Sensitivity of true $v_{1}$ FWHM to $\Omega_{A r}$. The $x$ axis represents the mean, and the horizontal error bars represent 1 standard deviation, of $\Omega_{\mathrm{Ar}}$ while aragonite precipitated in each experiment. The crosses indicate individual spectra, the filled points indicate means of each experiment, and the vertical error bars represent the standard error of replicate spectra. Colours indicate experiments conducted at various temperatures, and black circles indicate the two experiments conducted with elevated $\left[\mathrm{Ca}^{2+}\right]$. Grey shading represents the standard error of the curve fit to the individual spectra, and the dashed grey lines represent the standard error of prediction.

nificant variable was $\Omega_{\mathrm{Ar}}$ (Table 1 ). Together, this indicates that $\Omega_{\mathrm{Ar}}$ is likely the variable controlling $v_{1}$ FWHM, and that the correlations between $v_{1}$ FWHM and other factors may arise as artefacts of the correlations between those variables and $\Omega_{\mathrm{Ar}}$. The relationship between $\Omega_{\mathrm{Ar}}$ and $v_{1}$ FWHM is shown in Table 2 for measured and true FWHM on both the Horiba and WITec instruments (see Supplement for alternate calibration where $\Omega_{\mathrm{Ar}}$ is fit to $\nu_{1}$ FWHM). Uncertainty of the calibration propagates to an accuracy of derived $\Omega_{\mathrm{Ar}}$ of $\pm \sim 2$ for $\Omega_{\mathrm{Ar}}<20$, but increases to $\pm \sim 6$ at $\Omega_{\mathrm{Ar}}=30$ due to both the logarithmic shape of the relationship and the distance from the regression centre. The distributions of residuals were not significantly different from normal distributions (Kolmogorov-Smirnov test, $p>0.8$ ). FWHM data for each experiment are listed in Supplement Table S2.

Some uncertainty exists in defining the $\Omega_{\mathrm{Ar}}$ associated with each Raman spectrum, due to the variability of $\Omega_{\mathrm{Ar}}$ over the course of each abiogenic experiment. We conducted a Monte Carlo simulation using the data from the Horiba instrument to evaluate the variability in $v_{1}$ FWHM that is expected to arise from the uncertainty in $\Omega_{\mathrm{Ar}}$. In each of $10^{4}$ Monte Carlo iterations, we added random error to the mean $\Omega_{\text {Ar }}$ of each experiment, based on the standard deviation of measured $\Omega_{\mathrm{Ar}}$ and assuming a Gaussian distribution. Next, we calculated $\nu_{1}$ FWHM in each iteration based on $\Omega_{\mathrm{Ar}}$ (including the random error added) using the equation in $\mathrm{Ta}$ ble 2. The average standard deviation of the Monte Carlo 
Table 1. Linear model statistics for fits to $v_{1}$ FWHM.

\begin{tabular}{lrrrr}
\hline Model & $F$ value $^{\mathrm{a}}$ & $p$ value(s) & $r^{2}$ & Residual $\sigma^{\mathrm{b}}$ \\
\hline $\ln \left(\Omega_{\mathrm{Ar}}\right)$ & 186.4 & $\mathbf{< 0 . 0 0 1}$ & 0.70 & 0.165 \\
$\mathrm{Mg} / \mathrm{Ca}$ & 85.79 & $\mathbf{< 0 . 0 0 1}$ & 0.52 & 0.210 \\
$G$ & 0.77 & 0.383 & 0.0 & 0.304 \\
$\mathrm{CO}_{3}^{2-}$ & 133.9 & $\mathbf{< 0 . 0 0 1}$ & 0.63 & 0.185 \\
$\mathrm{pH}$ & 35.46 & $\mathbf{< 0 . 0 0 1}$ & 0.31 & 0.253 \\
$T$ & 6.75 & $\mathbf{0 . 0 1 1}$ & 0.07 & 0.293 \\
$v_{1}$ height & 4.50 & $\mathbf{0 . 0 3 7}$ & 0.04 & 0.297 \\
$v_{1}$ position & 0.06 & 0.807 & 0.02 & 0.289 \\
$\ln \left(\Omega_{\mathrm{Ar}}\right)+\mathrm{Mg} / \mathrm{Ca}$ & 92.97 & $<\mathbf{0 . 0 0 1}, 0.460$ & 0.70 & 0.166 \\
$\ln \left(\Omega_{\mathrm{Ar}}\right)+G$ & 92.02 & $<\mathbf{0 . 0 0 1}, 0.944$ & 0.70 & 0.166 \\
$\ln \left(\Omega_{\mathrm{Ar}}\right)+\mathrm{CO}{ }_{3}^{2-}$ & 95.91 & $<\mathbf{0 . 0 0 1}, 0.135$ & 0.71 & 0.164 \\
$\ln \left(\Omega_{\mathrm{Ar}}\right)+\mathrm{pH}$ & 97.43 & $\mathbf{< 0 . 0 0 1}, 0.079$ & 0.71 & 0.163 \\
$\ln \left(\Omega_{\mathrm{Ar}}\right)+T$ & 92.18 & $<\mathbf{0 . 0 0 1}, 0.755$ & 0.70 & 0.166 \\
$\ln \left(\Omega_{\mathrm{Ar}}\right)+v_{1}$ height & 92.02 & $<\mathbf{0 . 0 0 1}, 0.954$ & 0.70 & 0.166 \\
\hline
\end{tabular}

Notes: none of the multivariate models were significantly different from the $\Omega_{\mathrm{Ar}}$ model. ${ }^{\text {a }} 1.77$ degrees of freedom for univariate models, and 2.76 degrees of freedom for multivariate models; except for $v_{1}$ position, which had 1.59 degrees of freedom. ${ }^{b}$ Standard deviation $(1 \sigma)$ of the $v_{1}$ FWHM residuals from the model fit.

Table 2. Regression equations between mean $\nu_{1}$ FWHM and $\Omega_{\mathrm{Ar}}$.

\begin{tabular}{lrrrr}
\hline Calibration & Intercept & Slope & $r^{2}$ & Residual $\sigma$ \\
\hline Horiba measured & $1.62(0.17)$ & $0.70(0.06)$ & 0.85 & 0.09 \\
Horiba true & $0.94(0.19)$ & $0.79(0.06)$ & 0.85 & 0.11 \\
WITec measured & $2.09(0.14)$ & $0.57(0.05)$ & 0.96 & 0.05 \\
WITec true & $1.35(0.16)$ & $0.66(0.06)$ & 0.96 & 0.06
\end{tabular}

Notes: equations describe $v_{1} \mathrm{FWHM}=\operatorname{slope} \times \ln \left(\Omega_{\mathrm{Ar}}\right)+$ intercept, where the regressions were performed on the mean values of each experiment. Parentheses indicate 1 standard error.

$v_{1}$ FWHM residuals (the difference between the predicted and calculated $v_{1}$ FWHM in each iteration) was $0.24 \mathrm{~cm}^{-1}$, which is $50 \%$ greater than the observed standard deviation of the residuals $\left(0.16 \mathrm{~cm}^{-1}\right)$. Since the simulated variability exceeds the observed variability, one or more of the following is implied: (1) most (or all) of the scatter in $v_{1}$ FWHM around the regression line is explained by uncertainty of $\Omega_{\mathrm{Ar}}$, (2) the Raman spectra integrate signal from multiple crystals that together approximate the mean $\Omega_{\mathrm{Ar}}$ during each experiment, and/or (3) variability in $\Omega_{\mathrm{Ar}}$ is overestimated. Regardless, the data are consistent with a tight, logarithmic dependence of $v_{1}$ FWHM on $\Omega_{\mathrm{Ar}}$, with scatter in $\Omega_{\mathrm{Ar}}$ adding uncertainty to the observed relationship.

Analysis of 440 spectra collected from various grains of JCp-1 with the WITec instrument produced a mean measured $v_{1}$ FWHM of 3.51 with $1 \sigma$ of $\pm 0.09 \mathrm{~cm}^{-1}$ (true $v_{1}$ FWHM of $\left.2.99 \pm 0.11 \mathrm{~cm}^{-1}\right)$. Applying the calibration equation in Table 2 to calculate $\Omega_{\text {Ar }}$ for each of the 440 measurements of $v_{1}$ FWHM gave a mean derived $\Omega_{\text {Ar }}$ of 12.3 , with a standard deviation of 2.1, and a standard error of the mean of 0.3 .

In the Havannah Island coral, measured $v_{1}$ FWHM changed seasonally by $\sim 0.15 \mathrm{~cm}^{-1}$. Using our abiogenic calibration (Table 2) to estimate calcifying fluid $\Omega_{\mathrm{Ar}}$, these seasonal changes in FWHM translate to approximately $3 \Omega_{\mathrm{Ar}}$ units before the 1998 thermal stress event to approximately $1-2 \Omega_{\text {Ar }}$ units afterwards.

Measured $v_{1}$ FWHM of the cultured Acropora ranged from mean of 3.45 ( \pm 0.017 standard error $) \mathrm{cm}^{-1}$ for the control treatment to 3.366 ( \pm 0.009 standard error $) \mathrm{cm}^{-1}$ for the " $+\mathrm{CO}_{2}+T$ " treatment. Derived $\Omega_{\mathrm{Ar}}$ (from the abiogenic calibration) was significantly different among treatments. Tukey's test revealed significant decreases in $\Omega_{\mathrm{Ar}}$ as both $T$ $(p<0.001)$ and $\mathrm{CO}_{2}(p=0.045)$ increased. There was no significant interactive effect of $T$ and $\mathrm{CO}_{2}$.

$K_{\mathrm{D}}^{\mathrm{Mg} / \mathrm{Ca}}$ determined from the abiogenic aragonites was significantly positively correlated with $\Omega_{\text {Ar }}$ (Fig. 4; Supplement Table $\mathrm{S} 1 ; r^{2}=0.82$ for experiments conducted at $\left.25^{\circ} \mathrm{C}\right)$ :

$K_{\mathrm{D}}^{\mathrm{Mg} / \mathrm{Ca}}=\frac{(0.045 \pm 0.004) \Omega_{\mathrm{Ar}}+0.31 \pm 0.11}{1000}$.

The key finding of the $K_{\mathrm{D}}^{\mathrm{Mg} / \mathrm{Ca}}$ data for this study is the sensitivity to $\Omega_{\mathrm{Ar}}$ at a single temperature. This dependence of $K_{\mathrm{D}}^{\mathrm{Mg} / \mathrm{Ca}}$ on $\Omega_{\mathrm{Ar}}$ or precipitation rate was predicted by Gaetani and Cohen (2006) on the basis of the surface entrapment model proposed by Watson (2004), and was also observed in a recent abiogenic aragonite study (AlKhatib and Eisenhauer, 2017) (Fig. 4). Although our $K_{\mathrm{D}}^{\mathrm{Mg} / \mathrm{Ca}}$ data show a similar trend to those of AlKhatib and Eisenhauer (2017), their $K_{\mathrm{D}}^{\mathrm{Mg} / \mathrm{Ca}}$ are systematically lower. This offset is potentially explained by the different media used in the experiments: filtered seawater in DeCarlo et al. (2015) and Holcomb et al. (2016) as opposed to ammonium carbonate solutions in AlKhatib and Eisenhauer (2017). 

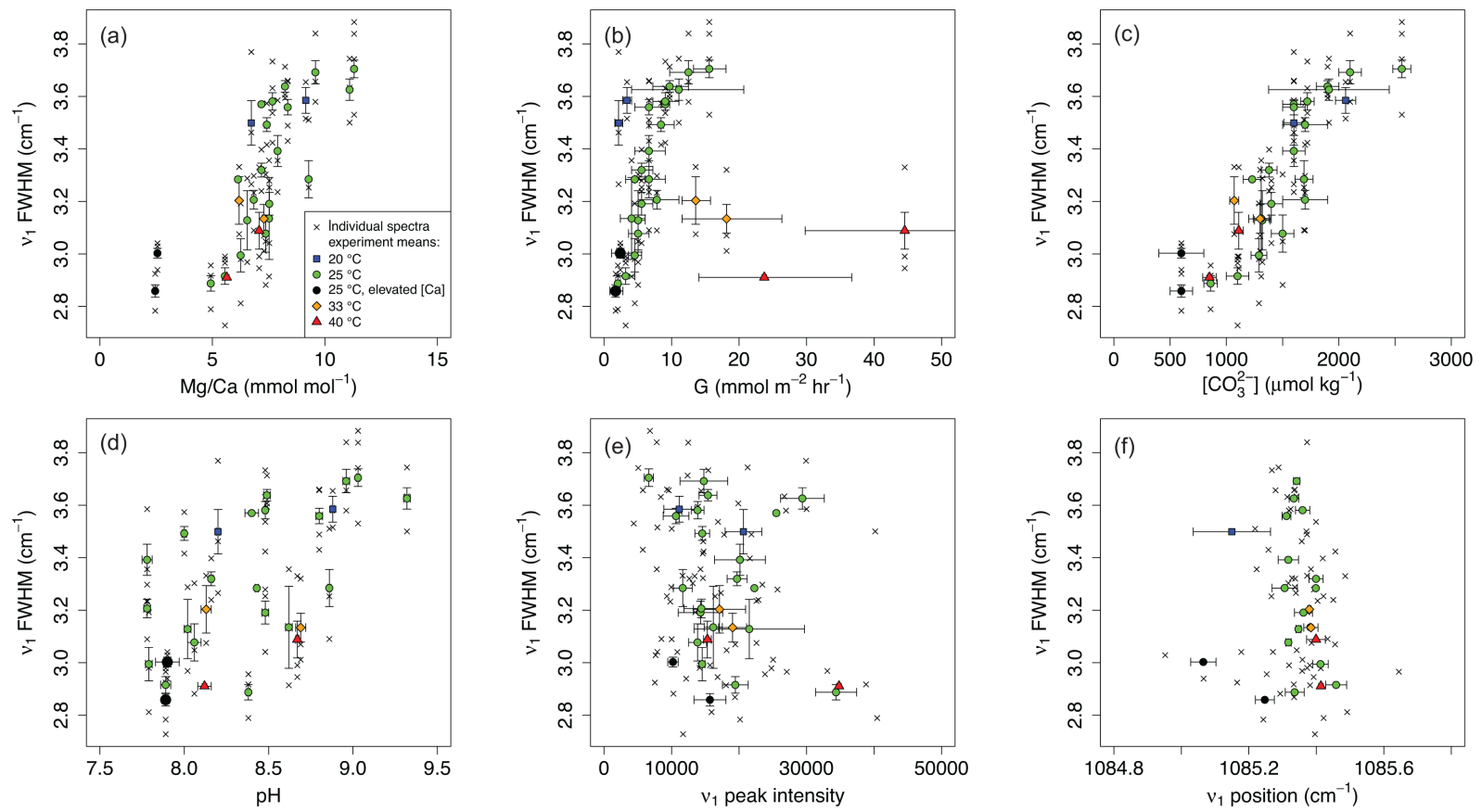

Figure 3. Scatter plots of Raman true peak width ( $v_{1}$ FWHM) and (a) aragonite $\mathrm{Mg} / \mathrm{Ca}$, (b) aragonite precipitation rate, (c) experimental fluid $\left[\mathrm{CO}_{3}^{2-}\right]$, (d) experimental fluid $\mathrm{pH}$, (e) Raman peak intensity, and (f) Raman peak position. Colours indicate experiments conducted at various temperatures, and black circles indicate the two experiments conducted with elevated $\left[\mathrm{Ca}^{2+}\right]$. While some apparent correlations exist, statistical models (Table 1) imply that $\Omega_{\mathrm{Ar}}$ is the variable controlling $v_{1}$ FWHM, and that the patterns observed here may be artefacts of correlations between these factors and $\Omega_{\mathrm{Ar}}$.

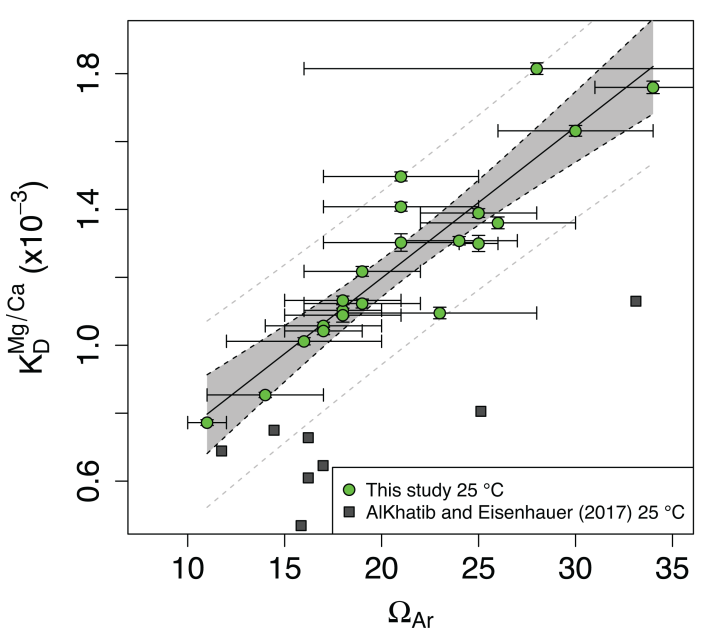

Figure 4. Sensitivity of $K_{\mathrm{D}}^{\mathrm{Mg} / \mathrm{Ca}}$ to $\Omega_{\mathrm{Ar}}$ at $25^{\circ} \mathrm{C}$. Horizontal error bars represent 1 standard deviation of $\Omega_{\mathrm{Ar}}$ while aragonite precipitated in each experiment. Grey shading represents the standard error of the curve, and the dashed grey lines represent the standard error of prediction. The grey squares show the AlKhatib and Eisenhauer (2017) data replotted against $\Omega_{\mathrm{Ar}}$ (see their Fig. 4 for a plot against precipitation rate).

\section{Discussion}

\subsection{Controls on aragonite $v_{1}$ peak width}

We conducted Raman spectroscopy analyses of abiogenic aragonites, precipitated under various carbonate chemistry and temperature treatments as previously described in DeCarlo et al. (2015) and Holcomb et al. (2016). Carbonate chemistry was manipulated in these experiments such that there is some independence between the carbonate system parameters, which allows us to isolate their effects on the Raman spectral peaks. For example, experiments conducted at the same $\Omega_{\mathrm{Ar}}$, but different temperatures, allow us to identify that $v_{1}$ FWHM is sensitive to $\Omega_{\mathrm{Ar}}$ but not to aragonite precipitation rate $(G)$ (Figs. 2 and 3b). Similarly, since $\mathrm{Sr} / \mathrm{Ca}$ is strongly controlled by temperature in these aragonites (DeCarlo et al., 2015), the lack of a temperature effect on $v_{1}$ FWHM implies that $\mathrm{Sr} / \mathrm{Ca}$ ratios exert minor or no effects on $v_{1}$ FWHM. Other factors were more difficult to isolate - for instance $\Omega_{\mathrm{Ar}}$ was correlated with both $\mathrm{Mg} / \mathrm{Ca}_{\text {solid }}$ and fluid $\left[\mathrm{CO}_{3}^{2-}\right]$. Yet comparisons among statistical models (Table 1) show that $\Omega_{\mathrm{Ar}}$ is the only variable that consistently has a significant effect on $v_{1}$ FWHM, regardless of which additional variable is considered in multivariate models. This leads us to conclude that $v_{1}$ FWHM is primarily dependent upon $\Omega_{\mathrm{Ar}}$. We also found that the scattering of data around the regression between $v_{1}$ FWHM and $\Omega_{\mathrm{Ar}}$ can be explained entirely 
by the uncertainty of $\Omega_{\mathrm{Ar}}$ in each experiment. Further, the absence of any significant correlations between $\nu_{1}$ FWHM and either $v_{1}$ position or height indicates that the variation of $v_{1}$ FWHM in our study was not the result of instrumental or curve-fitting artefacts.

Our ability to isolate the effect of $\Omega_{\mathrm{Ar}}$ from $\mathrm{Mg} / \mathrm{Ca}_{\text {solid }}$ and fluid $\left[\mathrm{CO}_{3}^{2-}\right]$ is best exemplified by the two experiments in which $\left[\mathrm{Ca}^{2+}\right]$ was elevated in the fluids by addition of dissolved $\mathrm{CaCO}_{3}$. Experiments f08 and g13 were conducted with mean fluid $\Omega_{\mathrm{Ar}}$ of 12 and 10 , and $\left[\mathrm{Ca}^{2+}\right]$ of 12.4 and $10.4 \mathrm{mmol} \mathrm{kg}^{-1}$, respectively, compared to the mean $\left[\mathrm{Ca}^{2+}\right]$ range of $6.9-8.7 \mathrm{mmol} \mathrm{kg}^{-1}$ in all other experiments. The addition of $\mathrm{Ca}^{2+}$ increased $\Omega_{\mathrm{Ar}}$, decreased $\mathrm{Mg} / \mathrm{Ca}$, and caused precipitation to occur at lower $\left[\mathrm{CO}_{3}^{2-}\right]$ than other experiments, thereby establishing some independence among these factors. Over the relatively narrow $\Omega_{\mathrm{Ar}}$ range of 10-12, which includes f08 and g13 as well as two experiments with lower $\left[\mathrm{Ca}^{2+}\right]$, there is still a positive correlation between $v_{1}$ FWHM and $\Omega_{\mathrm{Ar}}$ (Fig. 5a). Conversely, there are no clear patterns between $v_{1}$ FWHM and either $\mathrm{Mg} / \mathrm{Ca}$ or $\left[\mathrm{CO}_{3}^{2-}\right]$ across these four experiments (Fig. 5b-c). While this further demonstrates that $\Omega_{\mathrm{Ar}}$ is likely the factor directly controlling $v_{1}$ FWHM, more experiments designed to decouple $\Omega_{\mathrm{Ar}}, \mathrm{Mg} / \mathrm{Ca}$ and $\left[\mathrm{CO}_{3}^{2-}\right]$ will be useful for constraining $v_{1}$ FWHM sensitivities. In addition, whether the stoichiometry of $\left[\mathrm{Ca}^{2+}\right]$ and $\left[\mathrm{CO}_{3}^{2-}\right]$ affects $v_{1}$ FWHM will be an important question to address in future experiments (Nehrke et al., 2007).

The influence of $\Omega_{\mathrm{Ar}}$ on $v_{1}$ FWHM can be explained by carbonate ion disorder within the aragonite lattice, as originally hypothesized by Bischoff et al. (1985). Increasing $\Omega_{\mathrm{Ar}}$ causes more defects and/or impurities to be incorporated into the aragonite, increasing the positional disorder of carbonate in the lattice. The absence of a clear $\mathrm{Mg} / \mathrm{Ca}$ effect on $v_{1}$ FWHM (discussed further below) suggests that our observed changes in $v_{1}$ FWHM are related more to disorder in the lattice (i.e. more amorphous-like aragonites formed at higher $\Omega_{\mathrm{Ar}}$ ) than to trace element impurities. Disordered carbonate ions have a distribution of $\mathrm{C}-\mathrm{O}$ bond strengths and vibrational frequencies, which results in wider Raman peaks (Bischoff et al., 1985; Urmos et al., 1991; Perrin et al., 2016).

Raman spectroscopy studies of abiogenic $\mathrm{CaCO}_{3}$ have so far focused on calcite, vaterite, and amorphous $\mathrm{CaCO}_{3}$ (ACC) precipitated with wide ranges of $\mathrm{Mg} / \mathrm{Ca}$ (from 0 to $45 \mathrm{~mol} \%$ ) (Bischoff et al., 1985; Wehrmeister et al., 2009; Wang et al., 2012; Perrin et al., 2016). These studies manipulated the $\mathrm{Mg} / \mathrm{Ca}$ ratios of the solutions from which the precipitates formed, and they consistently reported strong correlations between $v_{1}$ FWHM and $v_{1}$ position, both of which increased with progressively higher $\mathrm{Mg} / \mathrm{Ca}$ in the solid phase. The abiogenic precipitates used in our study are different in that (1) they are aragonite, and (2) most of them (26 out of 28) were grown from the same parent solution (seawater) but under different carbonate chemistry treatments (DeCarlo et al., 2015; Holcomb et al., 2016). Most of the $\mathrm{Mg} / \mathrm{Ca}$ variability in these aragonites arises from the sensitivity of $\mathrm{Mg} / \mathrm{Ca}$ partitioning to $\Omega_{\mathrm{Ar}}$ (Fig. 4), not manipulation of $\mathrm{Mg} / \mathrm{Ca}$ in the initial fluid. Recognizing this methodological distinction is important for understanding why we did not find a correlation between $v_{1}$ FWHM and position. Firstly, aragonite has several orders of magnitude less $\mathrm{Mg}$ than high$\mathrm{Mg}$ calcites, potentially dampening the role of $\mathrm{Mg}$ in affecting the shape of the Raman peaks in aragonite. Secondly, if the trend between $\Omega_{\mathrm{Ar}}$ and $v_{1}$ FWHM were driven by $\mathrm{Mg}$ content alone, shifts in Raman peaks to higher wavenumbers would be expected, because $\mathrm{Mg}$ is lighter than Ca (Bischoff et al., 1985). However, there was no significant correlation between $v_{1}$ position and $\Omega_{\mathrm{Ar}}(p>0.7)$, indicating that the mean $\mathrm{C}-\mathrm{O}$ bond vibrational frequency did not change systematically with $\Omega_{\mathrm{Ar}}$. These observations imply that $\mathrm{Mg}$ content was not the primary source of lattice defects broadening Raman peaks, an interpretation supported by the absence of a correlation between $\mathrm{Mg} / \mathrm{Ca}$ and $v_{1}$ FWHM (after accounting for the effect of $\Omega_{\mathrm{Ar}}$; Table 1). The lack of correlation between $v_{1}$ FWHM and position also indicates that $v_{1}$ FWHM was unaffected by crystallite size (Urmos et al., 1991; Zakaria et al., 2008).

That fluid $\Omega_{\mathrm{Ar}}$, not $\mathrm{Mg} / \mathrm{Ca}_{\text {solid }}$, apparently controls $v_{1}$ FWHM in aragonite precipitated from seawater is critical for interpreting the Raman spectra of coral skeletons. Corals transport seawater to the micro-scale site of calcification (Gagnon et al., 2012; Tambutté et al., 2012), and much like in the abiogenic experiments of DeCarlo et al. (2015) and Holcomb et al. (2016), they precipitate aragonite crystals from a seawater-like solution (McConnaughey, 1989). Changes in calcifying fluid $\mathrm{Mg} / \mathrm{Ca}$ can result from $\mathrm{Ca}^{2+}$ transport and/or Rayleigh fractionation (Gaetani and Cohen, 2006; Gagnon et al., 2012). Yet $\mathrm{Mg} / \mathrm{Ca}$ in coral skeletons is generally within the limits of the abiogenic aragonites analysed here (2.5$11 \mathrm{mmol} \mathrm{mol}^{-1}$ ) and, critically, $v_{1}$ FWHM was insensitive to $\mathrm{Mg} / \mathrm{Ca}$ over this range. While it is still conceivable that $\mathrm{Mg} / \mathrm{Ca}$ or $\left[\mathrm{CO}_{3}^{2-}\right]$ could have some influence on coral $v_{1}$ FWHM, these effects are likely subordinate to the $\Omega_{\mathrm{Ar}}$ sensitivity based on our abiogenic results. This implies that we can interpret Raman spectra of coral skeletons using the abiogenic sensitivity of $v_{1}$ FWHM to $\Omega_{\mathrm{Ar}}$.

\subsection{Analysis of JCp-1 and relation to skeletal geochemistry}

Using Raman spectroscopy, we derived a mean calcifying fluid $\Omega_{\mathrm{Ar}}$ for the JCp-1 coral standard of $12.3 \pm 0.3$. JCp1 is an internationally calibrated geochemical standard, and has been analysed repeatedly for trace element and isotopic composition. Because the geochemistry of the skeleton reflects the calcifying fluid conditions, we can evaluate the accuracy of our $\Omega_{\mathrm{Ar}}$ estimates by comparing them to the reported geochemical properties of the JCp-1 carbonate. Specifically, here we calculate calcifying fluid calcium concentration $\left(\left[\mathrm{Ca}^{2+}\right]_{\mathrm{cf}}\right)$ using two different sets of proxies 

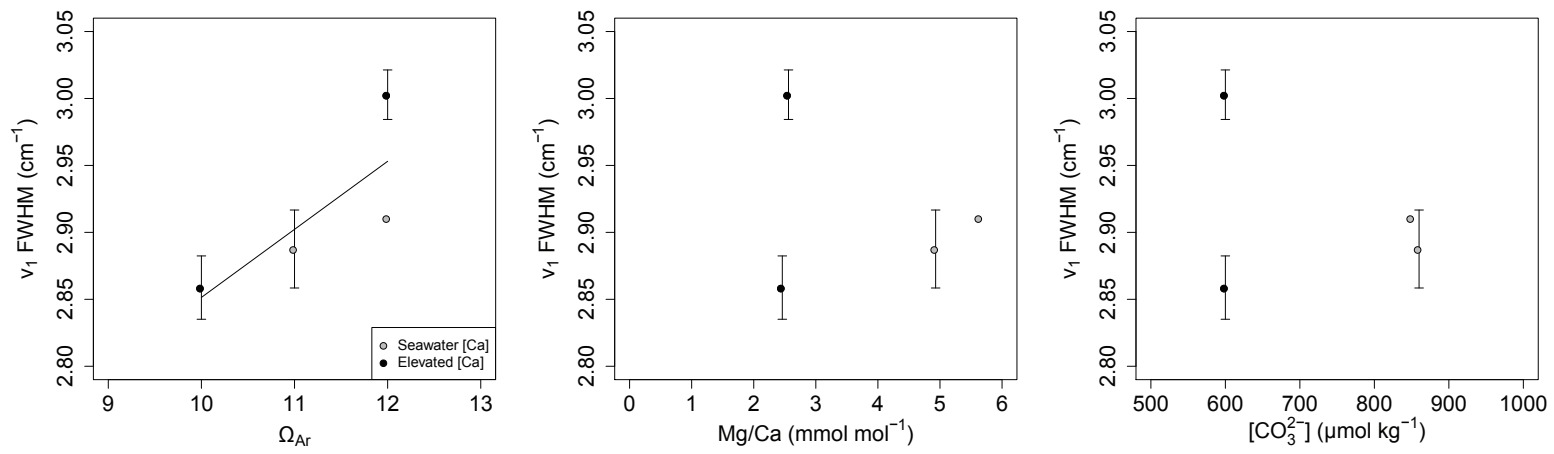

Figure 5. Isolation of $\Omega_{\mathrm{Ar}}, \mathrm{Mg} / \mathrm{Ca}$ and $\left[\mathrm{CO}_{3}^{2-}\right]$ controls on true $v_{1} \mathrm{FWHM}$ based on manipulation of fluid $\left[\mathrm{Ca}^{2+}\right]$. The same data are plotted here as in Figs. 2 and 3, but only over the $\Omega_{\mathrm{Ar}}$ range of 10-12 because it includes two experiments initiated with seawater $\left[\mathrm{Ca}^{2+}\right]$ (grey) and two experiments with elevated $\left[\mathrm{Ca}^{2+}\right]$ (black). With fluid $\left[\mathrm{Ca}^{2+}\right]$ manipulation, $v_{1}$ FWHM is still sensitive to $\Omega_{\mathrm{Ar}}(\mathbf{a})$, but not to $\mathrm{Mg} / \mathrm{Ca}$ (b) or $\left[\mathrm{CO}_{3}^{2-}\right](\mathbf{c})$.

- the first based on $\mathrm{Mg} / \mathrm{Ca}, \mathrm{Sr} / \mathrm{Ca}$, and $\delta^{44} \mathrm{Ca}$, and the second based on Raman, $\delta^{11} \mathrm{~B}$ (a pH proxy), and $\mathrm{B} / \mathrm{Ca}$ (see Appendix A for details of calculations). Our approach uses experimentally determined partitioning of these trace elements and isotopes between aragonite and seawater, and a simple model in which $\left[\mathrm{Ca}^{2+}\right]_{\mathrm{cf}}$ is initially elevated relative to seawater (Al-Horani et al., 2003) before precipitation from the isolated calcifying fluid (i.e. a closed system) drives Rayleigh fractionation (Gaetani and Cohen, 2006; Gaetani et al., 2011; Gagnon et al., 2012). We then compare these two independent $\left[\mathrm{Ca}^{2+}\right]_{\text {cf }}$ estimates to test whether our Raman results are consistent with $\mathrm{JCp}-1$ geochemistry.

The published $\mathrm{Mg} / \mathrm{Ca}, \mathrm{Sr} / \mathrm{Ca}$, and $\delta^{44} \mathrm{Ca}$ of the JCp1 coral can be explained with initial $\mathrm{Ca}^{2+}$ enrichment of $9-11 \%$ and precipitation of $48-59 \%$ of the total $\mathrm{Ca}^{2+}$. This corresponds to mean $\left[\mathrm{Ca}^{2+}\right]_{\mathrm{cf}}$ of $8.2 \pm 0.7 \mathrm{mmol} \mathrm{kg}{ }^{-1}$ (Fig. 6). We then independently estimated $\left[\mathrm{Ca}^{2+}\right]_{\mathrm{cf}}$ by combining our Raman spectroscopy results with boron systematics. The $\delta^{11} \mathrm{~B}$ and $\mathrm{B} / \mathrm{Ca}$ of JCp-1 together imply a calcifying fluid $\left[\mathrm{CO}_{3}^{2-}\right]$ of $987 \pm 78 \mu \mathrm{mol} \mathrm{kg}{ }^{-1}$. To reconcile the boronderived $\left[\mathrm{CO}_{3}^{2-}\right.$ ] with the Raman-derived $\Omega_{\mathrm{Ar}}$ of $12.3 \pm 0.3$ requires $\left[\mathrm{Ca}^{2+}\right]_{\text {cf }}$ of $8.3 \pm 0.7 \mathrm{mmol} \mathrm{kg}^{-1}$. This agrees almost exactly with the mean $\left[\mathrm{Ca}^{2+}\right]_{\mathrm{cf}}$ based on the calculations described above for $\mathrm{Mg} / \mathrm{Ca}, \mathrm{Sr} / \mathrm{Ca}$, and $\delta^{44} \mathrm{Ca}$ systematics (Fig. 6d), giving us confidence in the accuracy of our Raman-based $\Omega_{\text {Ar }}$ results. One implication of these results is that $\left[\mathrm{Ca}^{2+}\right]_{\mathrm{cf}}$ is less than seawater by $11-25 \%$, and while this finding should be replicated on additional corals, we note that depleted $\left[\mathrm{Ca}^{2+}\right]_{\mathrm{cf}}$ is consistent with trace element variability in deep-sea and surface-dwelling corals modelled using both "batch" and "flow-through" versions of the Rayleigh calculations (Gaetani et al., 2011; Gagnon et al., 2012). Further, our Raman-derived $\Omega_{\mathrm{Ar}}$ is generally consistent with estimates made on the basis of coral skeleton crystal aspect ratios (Cohen and Holcomb, 2009).

\subsection{High-resolution time series of calcifying fluid $\Omega_{\mathrm{Ar}}$}

Analysis of the Havannah Island coral demonstrates that Raman spectroscopy can detect variability in coral calcifying fluid $\Omega_{\mathrm{Ar}}$. The pattern of variability in Raman-derived $\Omega_{\mathrm{Ar}}$ showed some similarities, but also some differences, compared to the boron-derived $\Omega_{\mathrm{Ar}}$ presented in D'Olivo and McCulloch (2017). In a sampling track that avoided a 1998 partial-mortality scar ("path D"), boron-derived $\Omega_{\mathrm{Ar}}$ showed annual oscillations of 2-3 units, but one seasonal oscillation was completely missing during 1998/1999 (Fig. 7). Yet in a track directly adjacent to the scar ("path B"), boron-derived $\Omega_{\text {Ar }}$ showed overall lower values and less variability, compared to path $\mathrm{D}$. Raman-derived $\Omega_{\mathrm{Ar}}$ closely tracked variability of path D from 1996 to early 1998, then diverged from the boron-derived $\Omega_{\mathrm{Ar}}$ between mid-1998 and mid-1999, before returning to similar seasonal variability by 2000 .

There are several possible reasons for the differences between Raman- and boron-derived $\Omega_{\mathrm{Ar}}$. The first is that the Raman sampling path was located approximately halfway between boron paths B and $\mathrm{D}$, and thus there could be differences in $\Omega_{\mathrm{Ar}}$ across the skeleton. The boron data indicate lower $\Omega_{\mathrm{Ar}}$ near the partial-mortality scar, while the Raman data potentially reflect an intermediate level of bleaching stress between the low values of path $\mathrm{B}$ and the higher values of path $\mathrm{D}$. There is also potential for the existence of secondary precipitates near the scar, although the Raman spectra clearly indicated that only aragonite was present with no sign of calcite. Second, the Raman measurements have higher spatial resolution than the boron measurements, potentially allowing us to capture variability not observed in the boron sampling paths. Finally, boron-derived estimates of $\Omega_{\mathrm{Ar}}$ are based on the assumption that $\left[\mathrm{Ca}^{2+}\right]_{\mathrm{cf}}$ remains at, or close to, seawater concentrations, and therefore any substantial changes in $\left[\mathrm{Ca}^{2+}\right]_{\mathrm{cf}}$ will not be recorded in the boron-derived time series. This means that the decoupling 

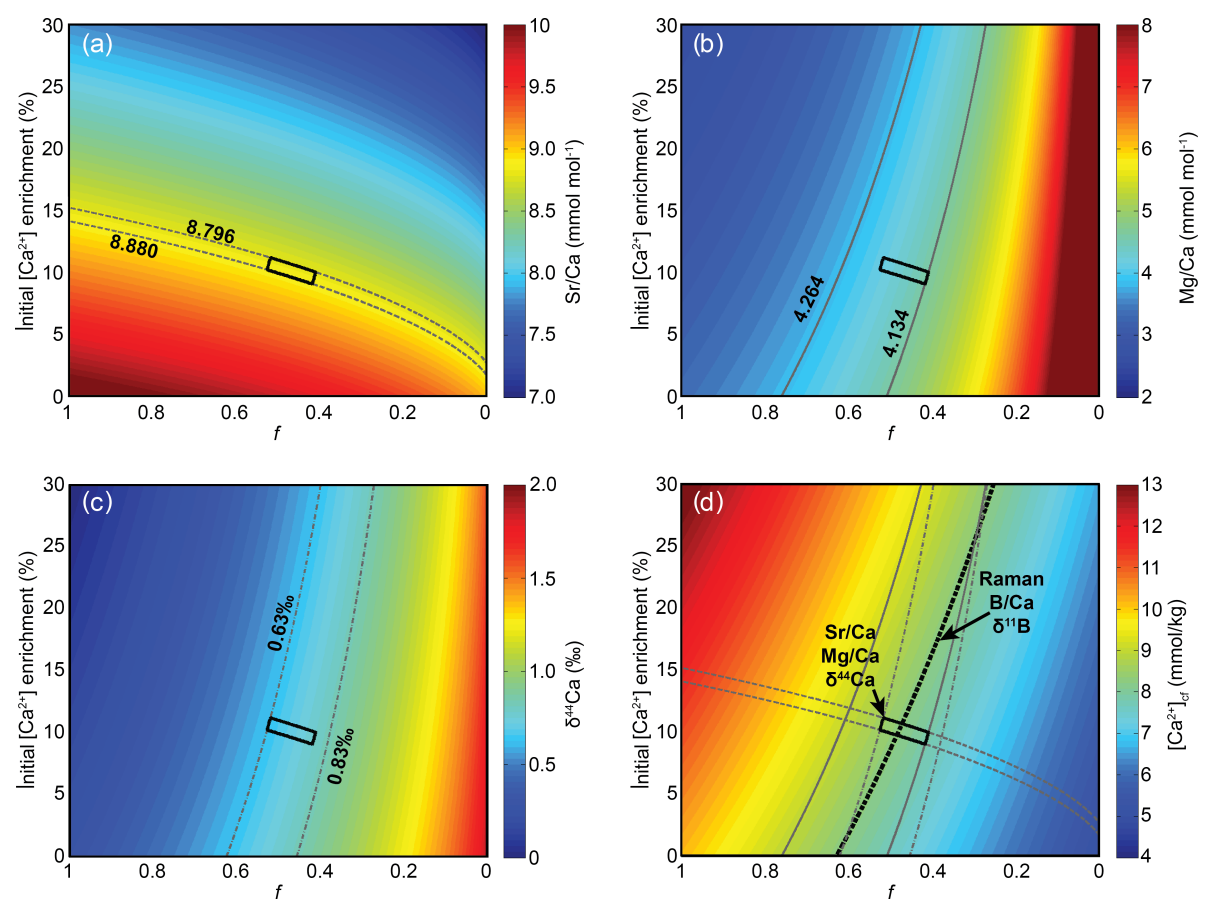

Figure 6. Evaluation of Raman-derived $\Omega_{\mathrm{Ar}}$ based on geochemistry of the JCp-1 coral. In each panel, the $x$ axis $f$ is fraction of total $\left[\mathrm{Ca}^{2+}\right]_{\mathrm{cf}}$ remaining, and the $y$ axis is initial $\left[\mathrm{Ca}^{2+}\right]_{\mathrm{cf}}$ enrichment relative to seawater. Colours indicate calculated (a) skeletal $\mathrm{Sr} / \mathrm{Ca}$, (b) skeletal $\mathrm{Mg} / \mathrm{Ca}$, (c) skeletal $\delta^{44} \mathrm{Ca}$, and $(\mathbf{d})\left[\mathrm{Ca}^{2+}\right]_{\mathrm{cf}}$. In (a-c) the grey lines bound the reported values of JCp-1 $( \pm 1 \sigma)$, and the black polygon shows the parameter space consistent with $\mathrm{Sr} / \mathrm{Ca}, \mathrm{Mg} / \mathrm{Ca}$, and $\delta^{44} \mathrm{Ca}$. Panel (d) shows $\left[\mathrm{Ca}^{2+}\right]_{\mathrm{cf}}$ and the grey lines show the constraints from panels $(\mathbf{a}-\mathbf{c})$. The dashed black line indicates the $\left[\mathrm{Ca}^{2+}\right]_{\mathrm{cf}}$ independently estimated based on combining our Raman data with published boron data (see text for details of the calculations). The two approaches are within error (i.e. the dashed black line intersects the solid black polygon) for Raman-derived $\Omega_{\mathrm{Ar}}$ between 10.8 and 13.7, consistent with the observed $\Omega_{\mathrm{Ar}}$ of $12.3 \pm 0.3$.

between Raman- and boron-derived $\Omega_{\mathrm{Ar}}$ from path $\mathrm{D}$ during 1998-1999 could reflect changes in $\left[\mathrm{Ca}^{2+}\right]_{\mathrm{cf}}$ (Fig. 7). D'Olivo and McCulloch (2017) showed that trace element ratios $(\mathrm{Mg} / \mathrm{Ca}$ and $\mathrm{Sr} / \mathrm{Ca})$ in path $\mathrm{B}$ indicated a strong reduction in $\left[\mathrm{Ca}^{2+}\right]_{\mathrm{cf}}$ during 1998 , although a consistent pattern was not observed in path D. Similarly, a recent study showed that $\mathrm{Mg} / \mathrm{Ca}$ and $\mathrm{Sr} / \mathrm{Ca}$ responses to bleaching in Porites from Western Australia were indicative of reduced $\left[\mathrm{Ca}^{2+}\right]_{\mathrm{cf}}$ (Clarke et al., 2017), consistent with our comparison between Raman and boron systematics in the Havannah Island coral. Mechanistically, reduced $\left[\mathrm{Ca}^{2+}\right]_{\mathrm{cf}}$ could result from decreases in the renewal rates of calcifying fluid (via increased Rayleigh fractionation) or decreases in $\mathrm{Ca}^{2+}$ addition to the calcifying fluid. While more studies are needed to test whether reduced $\left[\mathrm{Ca}^{2+}\right]_{\mathrm{cf}}$ is a consistent response to thermal stress, the ability to detect such changes by using Raman and boron systematics in tandem highlights their combined utility.

\subsection{Effects of temperature and $\mathrm{CO}_{2}$ on $\Omega_{\mathrm{Ar}}$ of juvenile Acropora}

Our analyses of juvenile Acropora indicate that calcifying fluid $\Omega_{\mathrm{Ar}}$ decreased in response to elevated temperature $\left(3^{\circ} \mathrm{C}\right.$ above the maximum monthly mean water temperature) and to elevated $\mathrm{CO}_{2}$ (Fig. 8). In micro-computed tomography (micro-CT) analyses of corals from the same experiment, Foster et al. (2016) showed that elevated $\mathrm{CO}_{2}$ increased skeletal porosity and decreased total calcification, while elevated temperature had the effect of partially mitigating the response to elevated $\mathrm{CO}_{2}$. Thus, the effect of elevated $\mathrm{CO}_{2}$ on Raman-derived $\Omega_{\mathrm{Ar}}$ is consistent with the calcification response, but thermal stress decreased $\Omega_{\text {Ar }}$ without having a negative impact on calcification. One possibility is that the effect of decreasing $\Omega_{\mathrm{Ar}}$ on aragonite accretion was balanced by elevated temperature, because aragonite crystal growth rates increase with both $\Omega_{\mathrm{Ar}}$ and temperature (Burton and Walter, 1987). Further, the physiological response to elevated temperature could be complex, potentially involving decreases in $\Omega_{\mathrm{Ar}}$ balanced by increases in calcifying time or surface area. Finally, Foster et al. (2016) found pitted skeletal surfaces indicative of dissolution, which may have compounded the measured $\mathrm{CO}_{2}$ effects on calcification and led to their dominance over any apparent effect of temperature in the " $+\mathrm{CO}_{2}+T$ " treatment. A recent study employing a similar experimental design found that juvenile Acropora $\mathrm{B} / \mathrm{Ca}$ and $\mathrm{U} / \mathrm{Ca}$ increased with elevated $\mathrm{CO}_{2}$ (Wu et al., 2017), both of which indicate decreases in calcifying fluid $\left[\mathrm{CO}_{3}^{2-}\right]$ 


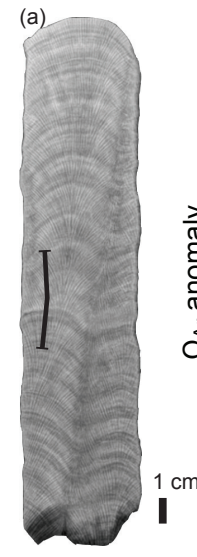

(b)

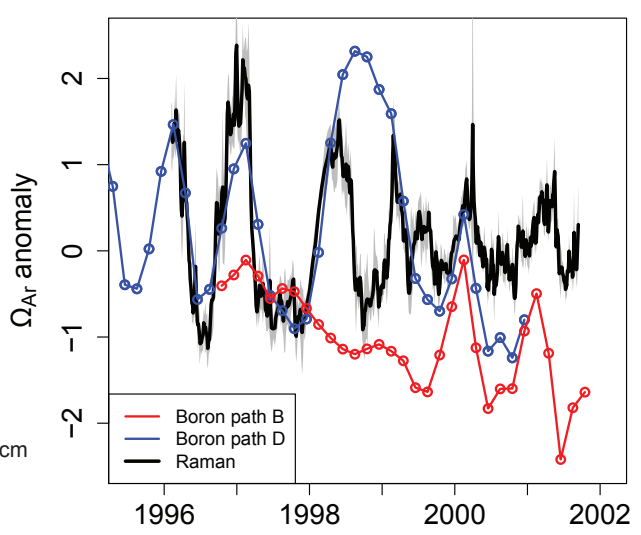

Figure 7. Time series of boron- and Raman-derived $\Omega_{\mathrm{Ar}}$ in a coral from Havannah Island. (a) X-ray image of central slab cut from the core. The black line indicates the Raman sampling path. Boron paths $\mathrm{B}$ and $\mathrm{D}$ were located approximately $1 \mathrm{~cm}$ into and out of the page, respectively (see Fig. 1 in D'Olivo and McCulloch (2017) for details). (b) The red and blue lines show boron-derived $\Omega_{\mathrm{Ar}}$ assuming a constant $\left[\mathrm{Ca}^{2+}\right]_{\mathrm{cf}}$. Raman-derived $\Omega_{\mathrm{Ar}}$ is plotted in black with grey error bars indicating $1 \sigma$. The means of the two data sets (mean of Raman $\Omega_{\text {Ar }}$ was 9.5) have been removed to facilitate comparison and because of uncertainty of absolute $\left[\mathrm{Ca}^{2+}\right]_{\mathrm{cf}}$ for the boron calculations.

based on abiogenic partitioning (DeCarlo et al., 2015; Holcomb et al., 2016). However, while elevated temperature increased $\delta^{11} \mathrm{~B}$ (i.e. increased $\mathrm{pH}$ ), it did not affect $\mathrm{B} / \mathrm{Ca}$ or $\mathrm{U} / \mathrm{Ca}$ (Wu et al., 2017), potentially reflecting the lower degree of thermal stress (culture temperatures were within the seasonal range at the collection site) compared to Foster et al. (2015) and/or that $\left[\mathrm{Ca}^{2+}\right]_{\mathrm{cf}}$ played an important role in our Raman data. Nevertheless, our results further highlight that Raman spectroscopy can detect changes in coral calcifying fluid $\Omega_{\mathrm{Ar}}$, and that this information is complementary to other analyses, including boron systematics (Sect. 4.3) as well as CT-derived porosity and calcification.

\section{Conclusions and outlook}

We tested whether Raman spectroscopy records the saturation state of the fluid from which aragonite precipitates. In abiogenic aragonites with known fluid conditions, we found a clear dependence of Raman peak width on $\Omega_{\mathrm{Ar}}$, an observation that is not confounded by other factors, including temperature, $\mathrm{Mg} / \mathrm{Ca}, \mathrm{pH}$, and $\left[\mathrm{CO}_{3}^{2-}\right]$. In the JCp-1 coral standard, for which calcifying fluid $\Omega_{\mathrm{Ar}}$ is not known directly, Raman-derived $\Omega_{\mathrm{Ar}}$ is consistent with multiple, independent lines of geochemical evidence based on $\mathrm{Mg} / \mathrm{Ca}$, $\mathrm{Sr} / \mathrm{Ca}, \mathrm{B} / \mathrm{Ca}, \delta^{11} \mathrm{~B}$, and $\delta^{44} \mathrm{Ca}$. These results support the use of Raman spectroscopy as a proxy for coral calcifying fluid $\Omega_{\mathrm{Ar}}$. While it remains theoretically possible for other fac-

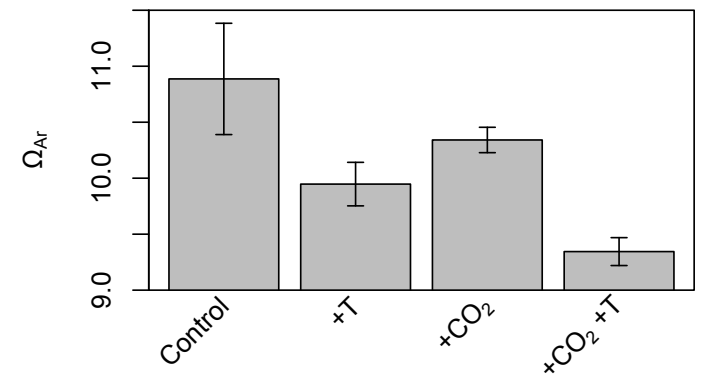

Figure 8. Raman-derived $\Omega_{\mathrm{Ar}}$ of Acropora cultured under different temperature and $\mathrm{CO}_{2}$ treatments. The grey bars indicate treatment means and error bars represent \pm standard error of the mean. Significant effects were observed for both temperature and $\mathrm{CO}_{2}$.

tors such as trace element variability to have some influence, our Raman results from abiogenic aragonites and the JCp-1 coral can be explained by $\Omega_{\mathrm{Ar}}$ alone. Nevertheless, future investigations of controls on Raman spectra of corals skeleton will be useful, for instance in checking for positive correlations between $v_{1}$ FWHM and wavenumber that would potentially indicate an effect of $\mathrm{Mg} / \mathrm{Ca}$ (Bischoff et al., 1985; Perrin et al., 2016; Borromeo et al., 2017). We found no such relationships in either our Porites or Acropora analyses ( $p>0.05, r^{2}<0.01$ in both cases).

Our approach could potentially be applied to other marine calcifiers that build aragonitic shells and skeletons, such as sclerosponges and some molluscs. However, the relationship between Raman peak width and $\Omega$ is likely to be mineralspecific. For example, calcite often contains magnesium with concentrations several orders of magnitude greater than in aragonite, which is likely the reason for the wider peaks in Raman spectra of calcite (Urmos et al., 1991). In contrast, we have shown that Raman spectroscopy is well suited for analysis of coral calcifying fluid $\Omega_{\mathrm{Ar}}$. Our initial applications to corals revealed annual cycles of Raman-derived $\Omega_{\mathrm{Ar}}$ in a field-collected Porites and $\Omega_{\mathrm{Ar}}$ responses to elevated temperature and $\mathrm{CO}_{2}$ in cultured Acropora, highlighting that Raman spectroscopy is indeed capable of detecting changes in coral calcifying fluid $\Omega_{\mathrm{Ar}}$. Additionally, the high spatial resolution $(<1 \mu \mathrm{m})$ and rapid sample processing $(\leq 1 \mathrm{~s}$ per spectrum) of Raman are currently unrivalled. Further, the same Raman spectra used to estimate $\Omega_{\mathrm{Ar}}$ can confirm that the sample is aragonite, effectively eliminating the possibility of contamination from other mineral phases. Finally, our analysis of JCp-1 suggests that the Raman $v_{1}$ FWHM may be an accurate proxy of fluid $\Omega_{\mathrm{Ar}}$, making it a complementary approach to $\mathrm{B} / \mathrm{Ca}$ and $\delta^{11} \mathrm{~B}$ because combining information from the two approaches enables us to calculate the full carbonate system via $\left[\mathrm{CO}_{3}^{2-}\right], \mathrm{pH}$, and possibly now $\left[\mathrm{Ca}^{2+}\right]_{\mathrm{cf}}$.

The $\Omega_{\mathrm{Ar}}$ of 12.3 that we derived for JCp- 1 corresponds to an instantaneous inorganic (Burton and Walter, 1987) aragonite precipitation rate of $0.2 \mathrm{~g} \mathrm{~cm}^{-2} \mathrm{yr}^{-1}$. This result is somewhat surprising because the average annual calcification 
rate of Porites living at $25^{\circ} \mathrm{C}$ is typically $1.3 \mathrm{~g} \mathrm{~cm}^{-2} \mathrm{yr}^{-1}$ (Lough, 2008), a factor of 6.5 faster than expected on the basis of the inorganic calcifying fluid $\Omega_{\text {Ar }}$ systematics. Since coral calyces have complex 3-D shape such that their skeletal surface area is actually much greater than the planar area of the colony surface (Barnes, 1970), this implies that calcifying surface area is an important factor in determining coral calcification rates (D'Olivo and McCulloch, 2017) and it complicates the use of bulk calcification rates for estimating $\Omega_{\mathrm{Ar}}$ (Raybaud et al., 2017). Multiple studies using micro-CT have shown increases in porosity and surface-area: volume ratios in corals cultured under elevated $\mathrm{CO}_{2}$ levels (Tambutté et al., 2015; Foster et al., 2016). This may represent a strategy for controlling calcifying surface area (i.e. the area over which crystals are precipitating from the calcifying fluid at a given time) to maintain bulk calcification rates and partially offset the impacts of ocean acidification.

In summary, recent studies and technological advances in boron isotope measurements (McCulloch et al., 2014), CT (DeCarlo and Cohen, 2016; Foster et al., 2016) and Raman spectroscopy (this study) are now making it increasingly feasible to quantify coral calcification responses with a multipronged approach. Future investigations combining Raman spectroscopy with $\mathrm{B} / \mathrm{Ca}, \delta^{11} \mathrm{~B}$, and porosity measurements on corals grown under elevated $\mathrm{CO}_{2}$ will be valuable for understanding mechanisms of resilience to ocean acidification. These include $\mathrm{pH}$ homeostasis, maintenance of high calcifying fluid $\Omega_{\mathrm{Ar}}$ by $\left[\mathrm{Ca}^{2+}\right]$ or $\left[\mathrm{CO}_{3}^{2-}\right]$ regulation, and increases in calcifying surface area as potential strategies for coral calcification to persist in a high- $\mathrm{CO}_{2}$ world. Evaluating their relative importance in the face of both increasing reef-water temperature and declining $\left[\mathrm{CO}_{3}^{2-}\right]$ will be critical to informing our predictions of where and when resilience may be found.
Code availability. An $\mathrm{R}$ code for Raman curve fitting is included in the Supplement. Codes for the full analysis is available at https://doi.org/10.24433/CO.ff54fd98-a010-43f5-ad6ac10c675387fc (DeCarlo, 2017a).

Data availability. Raman data are summarized in the Supplement. Individual Raman spectra are available in the Code Ocean link above and in the Zenodo "Raman spectra of marine calcifiers" community (https://zenodo.org/communities/calcifierraman/) at https://doi.org/10.5281/zenodo.1035493 (DeCarlo, 2017b). 


\section{Appendix A: Details of JCp-1 geochemistry calculations}

The JCp- 1 coral grew at an average temperature of $25^{\circ} \mathrm{C}$ (Okai et al., 2002), and the mean salinity in the area is 34.54 (Levitus, 2010). At $25^{\circ} \mathrm{C}$, the $K_{\mathrm{D}}^{\mathrm{Sr} / \mathrm{Ca}}$ is 1.123 (DeCarlo et al., $2015)$, and at $25^{\circ} \mathrm{C}$ and $\Omega_{\mathrm{Ar}}$ of $12, K_{\mathrm{D}}^{\mathrm{Mg} / \mathrm{Ca}}$ is $\sim 6.5( \pm 0.5) \times$ $10^{-4}$ (Fig. 4; in agreement with the mean value of AlKhatib and Eisenhauer (2017) at $<20 \Omega_{\mathrm{Ar}}$ and within error of our regression). We calculated a range of possible skeletal $\mathrm{Sr} / \mathrm{Ca}$ and $\mathrm{Mg} / \mathrm{Ca}$ ratios based on various combinations of $\mathrm{Ca}^{2+}$ pumping (enrichment of initial $\left[\mathrm{Ca}^{2+}\right]_{\mathrm{cf}}$ relative to seawater between 0 and $30 \%)$ and Rayleigh fractionation $(0$ $100 \%$ of total $\mathrm{Ca}^{2+}$ precipitated), and we compared the results to the known $\mathrm{Sr} / \mathrm{Ca}\left(8.838 \pm 0.042 \mathrm{mmol} \mathrm{mol}^{-1}\right)$ and $\mathrm{Mg} / \mathrm{Ca}\left(4.199 \pm 0.065 \mathrm{mmol} \mathrm{mol}^{-1}\right)$ ratios of JCp-1 (Fig. 6) (Hathorne et al., 2013). For $\delta^{44} \mathrm{Ca}$, we used the abiogenic aragonite fractionation factor (Gussone et al., 2003, 2005), seawater $\delta^{44} \mathrm{Ca}=1.88 \%$ (Hippler et al., 2003), Ca added via Ca-ATPase (i.e. $\left[\mathrm{Ca}^{2+}\right]_{\mathrm{cf}}$ enrichment) of $0.68 \%$ o (Inoue et al., 2015), and an average coral skeleton $\delta^{44} \mathrm{Ca}$ of $0.73 \pm 0.1$ (Inoue et al., 2015; Chen et al., 2016; Gothmann et al., 2016). Our calculation scheme utilized the Rayleigh equation

$\bar{j}_{\text {coral }}=\frac{i}{j_{\text {initial fluid }}} \frac{\left(1-f^{D}\right)}{1-f}$,

where $i / j$ is $\mathrm{Mg} / \mathrm{Ca}, \mathrm{Sr} / \mathrm{Ca}$, or ${ }^{44} \mathrm{Ca} /{ }^{40} \mathrm{Ca}, f$ is the fraction of Ca remaining; $D$ is $K_{\mathrm{D}}^{\mathrm{Mg} / \mathrm{Ca}}, K_{\mathrm{D}}^{\mathrm{Sr} / \mathrm{Ca}}$, or $\alpha_{44-40}$; and it is assumed that $\mathrm{Mg}$ and $\mathrm{Sr}$ concentrations in the initial fluid prior to precipitation are equal to those of seawater.

A similar result is achieved when considering the calcifying fluid as semi-closed and using the steady-state "flowthrough" model of Gagnon et al. (2012). We used the same $K_{\mathrm{D}}^{\mathrm{Mg} / \mathrm{Ca}}$ and $K_{\mathrm{D}}^{\mathrm{Sr} / \mathrm{Ca}}$ listed above and the equations of Gagnon et al. (2012) to solve for their " $\gamma$ " term (defined as the ratio of calcium pumping to precipitation) that best fit the JCp1 data (0.35). Next, we found the unique value of " $\frac{P}{k z \rho}$ " ( $3.1 \mathrm{mmol} \mathrm{Ca} \mathrm{kg}^{-1}$; where $P$ is precipitation flux, $k$ is seawater exchange rate, $z$ is the ratio of calcifying volume to surface area, and $\rho$ is seawater density) that was consistent with this $\gamma$ and the $\mathrm{JCp}-1 \mathrm{Mg} / \mathrm{Ca}$ and $\mathrm{Sr} / \mathrm{Ca}$. Finally, using these terms matched to JCp- 1 geochemistry, we follow the equation given in Gagnon et al. (2012):
$\left[\mathrm{Ca}^{2+}\right]_{\mathrm{cf}}=\left[\mathrm{Ca}^{2+}\right]_{\text {seawater }}-\frac{(1-\gamma) P}{k z \rho}$.

The $\left[\mathrm{Ca}^{2+}\right]_{\mathrm{cf}}$ calculated by this method is $8.1 \mathrm{mmol} \mathrm{kg}-1$, within error of the $8.2 \pm 0.7 \mathrm{mmol} \mathrm{kg}^{-1}$ derived from our "batch" model calculations above (see Fig. 6).

Our second approach to calculating $\left[\mathrm{Ca}^{2+}\right]_{\mathrm{cf}}$ combines Raman spectroscopy with boron systematics. JCp-1 has a $\mathrm{B} / \mathrm{Ca}$ ratio of $459.6 \pm 22.7 \mu \mathrm{mol} \mathrm{mol}^{-1}(1 \sigma)$ (Hathorne et al., 2013) and $\delta^{11} \mathrm{~B}$ of $24.3 \pm 0.17 \%$ o $(1 \sigma)$ (McCulloch et al., 2014). We used the isotope fractionation factor of Klochko et al. (2006) to determine $\mathrm{pH}$ from $\delta^{11} \mathrm{~B}$ assuming seawater $\delta^{11} \mathrm{~B}$ of $39.6 \%$ (Foster et al., 2010). Next, we used the parameterization of $p K_{\mathrm{B}}$ from Dickson (1990) to calculate $\left[\mathrm{B}(\mathrm{OH})_{4}^{-}\right]$from $\mathrm{pH}$, temperature, salinity, and assuming [B] equal to seawater $(411 \mu \mathrm{mol}$ $\mathrm{kg}^{-1}$ at salinity 34.54) (Allison et al., 2014). The $K_{\mathrm{D}}^{\mathrm{B} / \mathrm{Ca}}$ of Holcomb et al. (2016) was used to determine $\left[\mathrm{CO}_{3}^{2-}\right]$ from measured $\mathrm{B} / \mathrm{Ca}$ and calculated $\left[\mathrm{B}(\mathrm{OH})_{4}^{-}\right]$(computer code available at https://codeocean.com/2017/05/08/ boron-systematics-of-aragonite/interface, and see McCulloch et al., 2017). We then solve for $\left[\mathrm{Ca}^{2+}\right]_{\mathrm{cf}}$ with the following formula:

$\left[\mathrm{Ca}^{2+}\right]_{\mathrm{cf}}=\frac{\Omega_{\mathrm{Ar}}}{\left[\mathrm{CO}_{3}^{2-}\right]} K_{\mathrm{sp}}$,

where $\Omega_{\mathrm{Ar}}$ is derived from Raman spectroscopy and $K_{\mathrm{sp}}$ is the solubility product of aragonite in seawater. $\left[\mathrm{Ca}^{2+}\right]_{\mathrm{cf}}$ calculated in this way is $8.3 \pm 0.7 \mathrm{mmol} \mathrm{kg}^{-1}$.

In the first set of calculations with $\mathrm{Mg} / \mathrm{Ca}, \mathrm{Sr} / \mathrm{Ca}$, and $\delta^{44} \mathrm{Ca}$, we assume only that $\mathrm{Ca}^{2+}$ is added to the fluid, whereas in the second set of calculations with Raman spectroscopy and boron systematics we assume carbonate chemistry is modified from seawater. However, since we do not directly connect the initial $\mathrm{Ca}^{2+}$ enrichment of the fluid with the carbonate system calculations, we do not need to make assumptions regarding the stoichiometry of any potential proton- $\mathrm{Ca}^{2+}$ exchange. 
The Supplement related to this article is available online
at https://doi.org/10.5194/bg-14-5253-2017-supplement.

Author contributions. TMD conceived the idea, designed the study, conducted Raman measurements, and analysed the data. MH, JPD, TF, and MTM contributed materials and aided in the interpretation of results. TMD wrote the paper and all authors contributed to revising the final version.

Competing interests. The authors declare that they have no conflict of interest.

Acknowledgements. For the study of the GBR coral, Harry Clarke and Kai Rankenburg at University of Western Australia provided laboratory and analytical assistance. Facilities and technical assistance for the Acropora culturing experiments were provided by the Batavia Coast Maritime Institute, with logistical and technical support from the Basile family. Frieder Klein (WHOI) assisted with the initial Raman measurements. Funding was provided by an ARC Laureate Fellowship (FL120100049) awarded to Malcolm McCulloch and the ARC Centre of Excellence for Coral Reef Studies (CE140100020). The authors acknowledge the facilities, and the scientific and technical assistance of the Australian Microscopy \& Microanalysis Research Facility at the Centre for Microscopy, Characterisation \& Analysis, The University of Western Australia, a facility funded by the University, the Western Australian State and Commonwealth governments. Jan Fietzke and one anonymous reviewer provided constructive comments that improved a previous version of this paper.

Edited by: Lennart de Nooijer

Reviewed by: Jan Fietzke and one anonymous referee

\section{References}

Addadi, L., Raz, S., and Weiner, S.: Taking advantage of disorder: amorphous calcium carbonate and its roles in biomineralization, Adv. Mater., 15, 959-970, 2003.

Al-Horani, F. A., Al-Moghrabi, S. M., and De Beer, D.: The mechanism of calcification and its relation to photosynthesis and respiration in the scleractinian coral Galaxea fascicularis, Mar. Biol., 142, 419-426, https://doi.org/10.1007/s00227-002-09818, 2003.

AlKhatib, M. and Eisenhauer, A.: Calcium and Strontium Isotope Fractionation during Precipitation from Aqueous Solutions as a Function of Temperature and Reaction Rate; II. Aragonite, Geochim. Cosmochim. Ac., 209, 320-342, https://doi.org/10.1016/j.gca.2017.04.012, 2017.

Allison, N., Cohen, I., Finch, A. A., Erez, J., and Tudhope, A. W.: Corals concentrate dissolved inorganic carbon to facilitate calcification, Nature Commun., 5, 5741, https://doi.org/10.1038/ncomms6741, 2014.

Barkley, H. C., Cohen, A. L., Golbuu, Y., Starczak, V. R., DeCarlo, T. M., and Shamberger, K. E.: Changes in coral reef communities across a natural gradient in seawater $\mathrm{pH}$, Sci. Adv., 1, e1500328, https://doi.org/10.1126/sciadv.1500328, 2015.

Barkley, H. C., Cohen, A. L., McCorkle, D. C., and Golbuu, Y.: Mechanisms and thresholds for $\mathrm{pH}$ tolerance in Palau corals, J. Exp. Mar. Biol. Ecol., 489, 7-14, https://doi.org/10.1016/j.jembe.2017.01.003, 2017.

Barnes, D. J.: Coral skeletons: an explanation of their growth and structure, Science, 170, 1305-1308, https://doi.org/10.1126/science.170.3964.1305, 1970.

Bischoff, W. D., Sharma, S. K., and MacKenzie, F. T.: Carbonate ion disorder in synthetic and biogenic magnesian calcites; a Raman spectral study, Am. Mineral., 70, 581-589, 1985.

Borromeo, L., Zimmermann, U., Andò, S., Coletti, G., Bersani, D., Basso, D., Gentile, P., Schulz, B., and Garzanti, E.: Raman spectroscopy as a tool for magnesium estimation in $\mathrm{Mg}$-calcite, J. Raman Spectrosc., 48, 983-992, https://doi.org/10.1002/jrs.5156, 2017.

Brahmi, C., Meibom, A., Smith, D. C., Stolarski, J., AuzouxBordenave, S., Nouet, J., Doumenc, D., Djediat, C., and DomartCoulon, I.: Skeletal growth, ultrastructure and composition of the azooxanthellate scleractinian coral Balanophyllia regia, Coral Reefs, 29, 175-189, 2010.

Burton, E. A. and Walter, L. M.: Relative precipitation rates of aragonite and $\mathrm{Mg}$ calcite from seawater: Temperature or carbonate ion control?, Geology, 15, 111-114, 1987.

Cai, W.-J., Ma, Y., Hopkinson, B. M., Grottoli, A. G., Warner, M. E., Ding, Q., Hu, X., Yuan, X., Schoepf, V., Xu, H., Han, C., Melman, T. F., Hoadley, K. D., Pettay, D. T., Matsui, Y., Baumann, J. H., Levas, S., Ying, Y., and Wang, Y.: Microelectrode characterization of coral daytime interior $\mathrm{pH}$ and carbonate chemistry, Nature Commun., 7, 11144, https://doi.org/10.1038/ncomms11144, 2016.

Caldeira, K. and Wickett, M. E.: Anthropogenic carbon and ocean $\mathrm{pH}$, Nature, 425, 365, 2003.

Chan, N. C. S. and Connolly, S. R.: Sensitivity of coral calcification to ocean acidification: a meta-analysis, Glob. Change Biol., 19, 282-290, https://doi.org/10.1111/gcb.12011, 2013.

Chen, X., Deng, W., Zhu, H., Zhang, Z., Wei, G., and McCulloch, M. T.: Assessment of coral $\delta^{44 / 40} \mathrm{Ca}$ as a paleoclimate proxy in the Great Barrier Reef of Australia, Chem. Geol., 435, 71-78, https://doi.org/10.1016/j.chemgeo.2016.04.024, 2016.

Clarke, H., D'Olivo, J. P., Falter, J., Zinke, J., Lowe, R., and McCulloch, M.: Differential response of corals to regional mass-warming events as evident from skeletal $\mathrm{Sr} / \mathrm{Ca}$ and $\mathrm{Mg} / \mathrm{Ca}$ ratios, Geochem. Geophy. Geosy., 18, 1794-1809, https://doi.org/10.1002/2016GC006788, 2017.

Clode, P. and Marshall, A.: Low temperature FESEM of the calcifying interface of a scleractinian coral, Tissue and Cell, 34, 187198, https://doi.org/10.1016/S0040-8166(02)00031-9, 2002.

Clode, P. L., Lema, K., Saunders, M., and Weiner, S.: Skeletal mineralogy of newly settling Acropora millepora (Scleractinia) coral recruits, Coral Reefs, 30, 1-8, https://doi.org/10.1007/s00338010-0673-7, 2011.

Cohen, A. L. and Holcomb, M.: Why corals care about ocean acidification: uncovering the mechanism, Oceanography, 22, 118127, https://doi.org/10.5670/oceanog.2009.102, 2009.

Cohen, A. L. and McConnaughey, T. A.: Geochemical Perspectives on Coral Mineralization, Rev. Mineral. Geochem., 54, 151-187, https://doi.org/10.2113/0540151, 2003. 
Comeau, S., Tambutté, E., Carpenter, R. C., Edmunds, P. J., Evensen, N. R., Allemand, D., Ferrier-Pagès, C., Tambutté, S., and Venn, A. A.: Coral calcifying fluid $\mathrm{pH}$ is modulated by seawater carbonate chemistry not solely seawater $\mathrm{pH}$, Proceedings of the Royal Society of London B: Biological Sciences, 284, 2017.

Costanza, R., de Groot, R., Sutton, P., van der Ploeg, S., Anderson, S. J., Kubiszewski, I., Farber, S., and Turner, R. K.: Changes in the global value of ecosystem services, Glob. Environ. Chang., 26, 152-158, https://doi.org/10.1016/j.gloenvcha.2014.04.002, 2014.

Dandeu, A., Humbert, B., Carteret, C., Muhr, H., Plasari, E., and Bossoutrot, J. M.: Raman Spectroscopy - A Powerful Tool for the Quantitative Determination of the Composition of Polymorph Mixtures: Application to $\mathrm{CaCO}_{3}$ Polymorph Mixtures, Chem. Eng. Technol., 29, 221-225, https://doi.org/10.1002/ceat.200500354, 2006.

DeCarlo, T. M.: Data and code for "Coral calcifying fluid aragonite saturation states derived from Raman spectroscopy", available at: https://doi.org/10.5281/zenodo.1035493 (last access: November 2017), 2017.

DeCarlo, T. M.: Code for "Coral calcifying fluid aragonite saturation states derived from Raman spectroscopy", available at: https://doi.org/10.24433/CO.ff54fd98-a010-43f5-ad6ac10c675387fc (last access: November 2017), 2017.

DeCarlo, T. M. and Cohen, A. L.: coralCT: software tool to analyze computerized tomography (CT) scans of coral skeletal cores for calcification and bioerosion rates, available at: https://doi.org/10.5281/zenodo.57855 (last access: November 2017), 2016.

DeCarlo, T. M., Gaetani, G. A., Holcomb, M., and Cohen, A. L.: Experimental determination of factors controlling U/Ca of aragonite precipitated from seawater: implications for interpreting coral skeleton, Geochim. Cosmochim. Ac., 162, 151-165, https://doi.org/10.1016/j.gca.2015.04.016, 2015.

Dickson, A. G.: Standard potential of the reaction: $\mathrm{AgCl}(\mathrm{s})+1 / 2 \mathrm{H}_{2}$ $(\mathrm{g})=\mathrm{Ag}(\mathrm{s})+\mathrm{HCl}(\mathrm{aq})$, and the standard acidity constant of the ion $\mathrm{HSO}_{4}^{-}$in synthetic sea water from 273.15 to $318.15 \mathrm{~K}$, J. Chem. Thermodynam., 22, 113-127, 1990.

D’Olivo, J. P. and McCulloch, M. T.: Response of coral calcification and calcifying fluid composition to thermally induced bleaching stress, Scientific Reports, 7, 2207, 2017.

Doney, S. C., Fabry, V. J., Feely, R. A., and Kleypas, J. A.: Ocean acidification: the other $\mathrm{CO}_{2}$ problem, Mar. Sci., 1, 169-192, https://doi.org/10.1146/annurev.marine.010908.163834, 2009.

Fabricius, K. E., Langdon, C., Uthicke, S., Humphrey, C., Noonan, S., De'ath, G., Okazaki, R., Muehllehner, N., Glas, M. S., and Lough, J. M.: Losers and winners in coral reefs acclimatized to elevated carbon dioxide concentrations, Nature Clim. Change, 1, 165-169, 2011.

Foster, G. L., Pogge von Strandmann, P. A. E., and Rae, J. W. B.: Boron and magnesium isotopic composition of seawater, Geochem. Geophy. Geosy. 11, Q08015, https://doi.org/10.1029/2010GC003201, 2010.

Foster, T. and Clode, P. L.: Skeletal mineralogy of coral recruits under high temperature and $p \mathrm{CO}_{2}$, Biogeosciences, 13, 17171722, https://doi.org/10.5194/bg-13-1717-2016, 2016.

Foster, T., Gilmour, J. P., Chua, C. M., Falter, J. L., and McCulloch, M. T.: Effect of ocean warming and acidification on the early life stages of subtropical Acropora spicifera, Coral Reefs, 34, $1217-$ 1226, https://doi.org/10.1007/s00338-015-1342-7, 2015.

Foster, T., Falter, J. L., McCulloch, M. T., and Clode, P. L.: Ocean acidification causes structural deformities in juvenile coral skeletons, Science Advances, 2, e1501130, https://doi.org/10.1126/sciadv.1501130, 2016.

Gaetani, G. A. and Cohen, A. L.: Element partitioning during precipitation of aragonite from seawater: A framework for understanding paleoproxies, Geochim. Cosmochim. Ac., 70, 46174634, https://doi.org/10.1016/j.gca.2006.07.008, 2006.

Gaetani, G. A., Cohen, A. L., Wang, Z., and Crusius, J.: Rayleigh-Based, Multi-Element Coral Thermometry: a Biomineralization Approach to Developing Climate Proxies, Geochim. Cosmochim. Ac., 75, 1920-1932, https://doi.org/10.1016/j.gca.2011.01.010, 2011.

Gagnon, A. C., Adkins, J. F., and Erez, J.: Seawater transport during coral biomineralization, Earth Planet. Sc. Lett., 329, 150-161, 2012.

Gattuso, J.-P., Frankignoulle, M., Bourge, I., Romaine, S., and Buddemeier, R.: Effect of calcium carbonate saturation of seawater on coral calcification, Global Planet. Change, 18, 37-46, https://doi.org/10.1016/S0921-8181(98)00035-6, 1998.

Gattuso, J. P., Allemand, D., and Frankignoulle, M.: Photosynthesis and calcification at cellular, organismal and community levels in coral reefs: a review on interactions and control by carbonate chemistry, Am. Zool., 39, 160-183, https://doi.org/10.1093/icb/39.1.160, 1999.

Georgiou, L., Falter, J., Trotter, J., Kline, D. I., Holcomb, M., Dove, S. G., Hoegh-Guldberg, O., and McCulloch, M.: $\mathrm{pH}$ homeostasis during coral calcification in a free ocean $\mathrm{CO}_{2}$ enrichment (FOCE) experiment, Heron Island reef flat, Great Barrier Reef, P. Natl. Acad. Sci., 112, 13219-13224, https://doi.org/10.1073/pnas.1505586112, 2015.

Gothmann, A. M., Bender, M. L., Blättler, C. L., Swart, P. K., Giri, S. J., Adkins, J. F., Stolarski, J., and Higgins, J. A.: Calcium isotopes in scleractinian fossil corals since the Mesozoic: Implications for vital effects and biomineralization through time, Earth Planet. Sc. Lett., 444, 205-214, https://doi.org/10.1016/j.eps1.2016.03.012, 2016.

Gussone, N., Eisenhauer, A., Heuser, A., Dietzel, M., Bock, B., Böhm, F., Spero, H. J., Lea, D. W., Bijma, J., and Nägler, T. F.: Model for kinetic effects on calcium isotope fractionation $\left(\delta^{44} \mathrm{Ca}\right)$ in inorganic aragonite and cultured planktonic foraminifera, Geochim. Cosmochim. Ac., 67, 1375-1382, https://doi.org/10.1016/S0016-7037(02)01296-6, 2003.

Gussone, N., Böhm, F., Eisenhauer, A., Dietzel, M., Heuser, A., Teichert, B. M., Reitner, J., Wörheide, G., and Dullo, W.-C.: Calcium isotope fractionation in calcite and aragonite, Geochim. Cosmochim. Ac., 69, 4485-4494, https://doi.org/10.1016/j.gca.2005.06.003, 2005.

Hathorne, E. C., Gagnon, A., Felis, T., Adkins, J., Asami, R., Boer, W., Caillon, N., Case, D., Cobb, K. M., Douville, E., DeMenocal, P., Eisenhauer, A., Garbe-Schönberg, D., Geibert, W., Goldstein, S., Hughen, K., Inoue, M., Kawahata, H., Kölling, M., Cornec, F. L., Linsley, B. K., McGregor, H. V., Montagna, P., Nurhati, I. S., Quinn, T. M., Raddatz, J., Rebaubier, H., Robinson, L., Sadekov, A., Sherrell, R., Sinclair, D., Tudhope, A. W., Wei, G., Wong, H., Wu, H. C., and You, C.-F.: Interlaboratory study for coral $\mathrm{Sr} / \mathrm{Ca}$ and other element/Ca ra- 
tio measurements, Geochem. Geophy. Geosy., 14, 3730-3750, https://doi.org/10.1002/ggge.20230, 2013.

Hennige, S. J., Morrison, C. L., Form, A. U., Büscher, J., Kamenos, N. A., and Roberts, J. M.: Self-recognition in corals facilitates deep-sea habitat engineering, Scientific Reports, 4, 6782, https://doi.org/10.1038/srep06782, 2014.

Hennige, S. J., Wicks, L. C., Kamenos, N. A., Perna, G., Findlay, H. S., and Roberts, J. M.: Hidden impacts of ocean acidification to live and dead coral framework., Proceedings Biological sciences / The Royal Society, 282, 20150990, https://doi.org/10.1098/rspb.2015.0990, 2015.

Hippler, D., Schmitt, A.-D., Gussone, N., Heuser, A., Stille, P., Eisenhauer, A., and Nägler, T. F.: Calcium Isotopic Composition of Various Reference Materials and Seawater, Geostand. Geoanal. Res., 27, 13-19, https://doi.org/10.1111/j.1751908X.2003.tb00709.x, 2003.

Hoegh-Guldberg, O., Mumby, P. J., Hooten, A. J., Steneck, R. S., Greenfield, P., Gomez, E., Harvell, C. D., Sale, P. F., Edwards, A. J., and Caldeira, K.: Coral reefs under rapid climate change and ocean acidification, Science, 318, 1737-1742, https://doi.org/10.1126/science.1152509, 2007.

Hoegh-Guldberg, O., Cai, R., Poloczanska, E., Brewer, P., Sundby, S., Helmi, K., Fabry, V., and Jung, S.: The Ocean, in: Climate Change 2014: Impacts, Adaptation, and Vulnerability. Contribution of Working Group 2 to the Fifth Assessment Report of the Intergovernmental Panel on Climate Change, edited by Barros, V., Field, C., Dokken, D., Mastrandrea, M., Mach, K., Bilir, T., Chatterjee, M., Ebi, K., Estrada, Y., Genova, R., Girma, B., Kissel, E., Levy, A., MacCracken, S., Mastrandrea, P., and White, L., Cambridge University Press, Cambridge, United Kingdom and New York, NY, USA, 2014.

Holcomb, M., Venn, A. A., Tambutté, E., Tambutté, S., Allemand, D., Trotter, J., and McCulloch, M.: Coral calcifying fluid $\mathrm{pH}$ dictates response to ocean acidification, Scientific Reports, 4, 2014.

Holcomb, M., DeCarlo, T., Gaetani, G., and McCulloch, M.: Factors affecting B/Ca ratios in synthetic aragonite, Chem. Geol., 437, 67-76, https://doi.org/10.1016/j.chemgeo.2016.05.007, 2016.

Hönisch, B., Ridgwell, A., Schmidt, D. N., Thomas, E., Gibbs, S. J., Sluijs, A., Zeebe, R., Kump, L., Martindale, R. C., and Greene, S. E.: The geological record of ocean acidification, Science, 335, 1058-1063, https://doi.org/10.1126/science.1208277, 2012.

Inoue, M., Gussone, N., Koga, Y., Iwase, A., Suzuki, A., Sakai, K., and Kawahata, H.: Controlling factors of $\mathrm{Ca}$ isotope fractionation in scleractinian corals evaluated by temperature, $\mathrm{pH}$ and light controlled culture experiments, Geochim. Cosmochim. Ac., 167, 80-92, https://doi.org/10.1016/j.gca.2015.06.009, 2015.

Kamenos, N. A., Burdett, H. L., Aloisio, E., Findlay, H. S., Martin, S., Longbone, C., Dunn, J., Widdicombe, S., and Calosi, P.: Coralline algal structure is more sensitive to rate, rather than the magnitude, of ocean acidification, Glob. Change Biol., 19, 36213628, 2013.

Kamenos, N. A., Perna, G., Gambi, M. C., Micheli, F., and Kroeker, K. J.: Coralline algae in a naturally acidified ecosystem persist by maintaining control of skeletal mineralogy and size, Proceedings of the Royal Society of London B: Biological Sciences, 283, 2016.

Kinsman, D. J. J. and Holland, H. D.: The co-precipitation of cations with $\mathrm{CaCO}_{3}$-IV. The co-precipitation of $\mathrm{Sr}^{2+}$ with arago- nite between 16 and 96 C, Geochim. Cosmochim. Ac., 33, 1-17, https://doi.org/10.1016/0016-7037(69)90089-1, 1969.

Knowlton, N., Brainard, R. E., Fisher, R., Moews, M., Plaisance, L., and Caley, M.: Coral Reef Biodiversity, in: Life in the World's Oceans: Diversity, Distribution, and Abundance, 2010.

Kubota, K., Yokoyama, Y., Ishikawa, T., and Suzuki, A.: A new method for calibrating a boron isotope paleo-pH proxy using massive Porites corals, Geochem. Geophy. Geosy., 16, 33333342, https://doi.org/10.1002/2015GC005975, 2015.

Levitus, S.: NOAA Atlas NESDIS 68-71, US Government Printing Office, Washington, D.C., 2010.

Lin, F., Sum, A. K., and Bodnar, R. J.: Correlation of methane Raman $v_{1}$ band position with fluid density and interactions at the molecular level, J. Raman Spectrosc., 38, 1510-1515, https://doi.org/10.1002/jrs.1804, 2007.

Lough, J.: Coral calcification from skeletal records revisited, Mar. Ecol. Prog. Ser., 373, 257-264, https://doi.org/10.3354/meps07398, 2008.

McConnaughey, T.: ${ }^{13} \mathrm{C}$ and ${ }^{18} \mathrm{O}$ isotopic disequilibrium in biological carbonates: I. Patterns, Geochim. Cosmochim. Ac., 53, 151162, https://doi.org/10.1016/0016-7037(89)90282-2, 1989.

McCulloch, M. T., Falter, J., Trotter, J., and Montagna, P.: Coral resilience to ocean acidification and global warming through $\mathrm{pH}$ up-regulation, Nature Climate Change, 2, 623-627, 2012.

McCulloch, M. T., Holcomb, M., Rankenburg, K., and Trotter, J. A.: Rapid, high-precision measurements of boron isotopic compositions in marine carbonates, Rap. Commun. Mass Spectrom., 28, 2704-2712, https://doi.org/10.1002/rcm.7065, 2014.

McCulloch, M. T., D’Olivo Cordero, J. P., Falter, J., Holcomb, M., and Trotter, J. A.: Coral calcification in a changing World: the interactive dynamics of $\mathrm{pH}$ and DIC up-regulation, Nature Commun., 8, 15686, https://doi.org/10.1038/ncomms15686, 2017.

McElderry, J.-D. P., Zhu, P., Mroue, K. H., Xu, J., Pavan, B., Fang, M., Zhao, G., McNerny, E., Kohn, D. H., Franceschi, R. T., Holl, M. M., Tecklenburg, M. M., Ramamoorthy, A., and Morris, M. D.: Crystallinity and compositional changes in carbonated apatites: Evidence from ${ }^{31} \mathrm{P}$ solid-state NMR, Raman, and AFM analysis, J. Solid State Chem., 206, 192-198, https://doi.org/10.1016/j.jssc.2013.08.011, 2013.

Montagna, P., McCulloch, M., Douville, E., López Correa, M., Trotter, J., Rodolfo-Metalpa, R., Dissard, D., FerrierPagès, C., Frank, N., Freiwald, A., Goldstein, S., Mazzoli, C., Reynaud, S., Rüggeberg, A., Russo, S., and Taviani, M.: Li/Mg systematics in scleractinian corals: Calibration of the thermometer, Geochim. Cosmochim. Ac., 132, 288-310, https://doi.org/10.1016/j.gca.2014.02.005, 2014.

Nasdala, L., Wenzel, M., Vavra, G., Irmer, G., Wenzel, T., and Kober, B.: Metamictisation of natural zircon: accumulation versus thermal annealing of radioactivity-induced damage, Contributions to Mineralogy and Petrology, 141, 125-144, https://doi.org/10.1007/s004100000235, 2001.

Nehrke, G., Reichart, G., Van Cappellen, P., Meile, C., and Bijma, J.: Dependence of calcite growth rate and $\mathrm{Sr}$ partitioning on solution stoichiometry: Non-Kossel crystal growth, Geochim. Cosmochim. Ac., 71, 2240-2249, https://doi.org/10.1016/J.GCA.2007.02.002, 2007.

Nehrke, G. and Nouet, J.: Confocal Raman microscope mapping as a tool to describe different mineral and organic phases at high spatial resolution within marine biogenic carbonates: case study 
on Nerita undata (Gastropoda, Neritopsina), Biogeosciences, 8, 3761-3769, https://doi.org/10.5194/bg-8-3761-2011, 2011.

Okai, T., Suzuki, A., Kawahata, H., Terashima, S., and Imai, N.: Preparation of a New Geological Survey of Japan Geochemical Reference Material: Coral JCp-1, Geostandards Newsletter, 26, 95-99, https://doi.org/10.1111/j.1751-908X.2002.tb00627.x, 2002.

Pandolfi, J. M., Connolly, S. R., Marshall, D. J., and Cohen, A. L.: Projecting coral reef futures under global warming and ocean acidification, Science, 333, 418-422, 2011.

Pauly, M., Kamenos, N. A., Donohue, P., and LeDrew, E.: Coralline algal $\mathrm{Mg}-\mathrm{O}$ bond strength as a marine $p \mathrm{CO}_{2}$ proxy, Geology, 43, 267-270, https://doi.org/10.1130/G36386.1, 2015.

Perrin, J., Vielzeuf, D., Laporte, D., Ricolleau, A., Rossman, G. R., and Floquet, N.: Raman characterization of synthetic magnesian calcites, American Mineralogist, 101, 2525-2538, 2016.

Raybaud, V., Tambutté, S., Ferrier-Pagès, C., Reynaud, S., Venn, A. A., Tambutté, É., Nival, P., and Allemand, D.: Computing the carbonate chemistry of the coral calcifying medium and its response to ocean acidification, J. Theor. Biol., 424, 26-36, https://doi.org/10.1016/j.jtbi.2017.04.028, 2017.

R Core Team: R: A language and environment for statistical computing, 2016.

Ries, J. B.: A physicochemical framework for interpreting the biological calcification response to $\mathrm{CO}_{2}$-induced ocean acidification, Geochim. Cosmochim. Ac., 75, 4053-4064, 2011.

Riley, J. P. and Tongudai, M.: The major cation/chlorinity ratios in sea water, Chem. Geol., 2, 263-269, 1967.

Roger, L. M., George, A. D., Shaw, J., Hart, R. D., Roberts, M., Becker, T., McDonald, B. J., and Evans, N. J.: Geochemical and microstructural characterisation of two species of cool-water bivalves (Fulvia tenuicostata and Soletellina biradiata) from Western Australia, Biogeosciences, 14, 1721-1737, https://doi.org/10.5194/bg-14-1721-2017, 2017.

Shamberger, K. E., Cohen, A. L., Golbuu, Y., McCorkle, D. C., Lentz, S. J., and Barkley, H. C.: Diverse coral communities in naturally acidified waters of a Western Pacific reef, Geophys. Res. Lett., 41, 499-504, https://doi.org/10.1002/2013GL058489, 2014.

Smith, E. and Dent, G.: Modern Raman spectroscopy: a practical approach, John Wiley \& Sons, West Sussex, England, 2005.

Stock, S. R., Veis, A., Xiao, X., Almer, J. D., and Dorvee, J. R.: Sea urchin tooth mineralization: Calcite present early in the aboral plumula, J. Struct. Biol., 180, 280-289, https://doi.org/10.1016/j.jsb.2012.08.004, 2012.

Stolarski, J., Bosellini, F. R., Wallace, C. C., Gothmann, A. M., Mazur, M., Domart-Coulon, I., Gutner-Hoch, E., Neuser, R. D., Levy, O., Shemesh, A., and Meibom, A.: A unique coral biomineralization pattern has resisted 40 million years of major ocean chemistry change., Scientific Reports, 6, 27579, https://doi.org/10.1038/srep27579, 2016.

Tambutté, E., Tambutté, S., Segonds, N., Zoccola, D., Venn, A., Erez, J., and Allemand, D.: Calcein labelling and electrophysiology: insights on coral tissue permeability and calcification, Proceedings of the Royal Society B: Biological Sciences, 279, 19-27, https://doi.org/10.1098/rspb.2011.0733, 2012.

Tambutté, E., Venn, A. A., Holcomb, M., Segonds, N., Techer, N., Zoccola, D., Allemand, D., and Tambutté, S.: Morphological plasticity of the coral skeleton under $\mathrm{CO}_{2}$-driven seawater acidification, Nature Communications, 6, 7368, https://doi.org/10.1038/ncomms8368, 2015.

Trotter, J., Montagna, P., McCulloch, M., Silenzi, S., Reynaud, S., Mortimer, G., Martin, S., Ferrier-Pagès, C., Gattuso, J. P., and Rodolfo-Metalpa, R.: Quantifying the $\mathrm{pH}$ 'vital effect' in the temperate zooxanthellate coral Cladocora caespitosa: Validation of the boron seawater pH proxy, Earth Planet. Sc. Lett., 303, 163173, 2011.

Urmos, J., Sharma, S. K., and Mackenzie, F. T.: Characterization of some biogenic carbonates with Raman spectroscopy, American Mineralogist, 76, 641-646, 1991.

Váczi, T.: A New, Simple Approximation for the Deconvolution of Instrumental Broadening in Spectroscopic Band Profiles, Appl. Spectrosc., 68, 1274-1278, https://doi.org/10.1366/1307275, 2014.

Venn, A., Tambutte, E., Holcomb, M., Allemand, D., and Tambutte, S.: Live tissue imaging shows reef corals elevate $\mathrm{pH}$ under their calcifying tissue relative to seawater, PLoS One, 6, e20013, https://doi.org/10.1371/journal.pone.0020013, 2011.

Wall, M. and Nehrke, G.: Reconstructing skeletal fiber arrangement and growth mode in the coral Porites lutea (Cnidaria, Scleractinia): a confocal Raman microscopy study, Biogeosciences, 9, 4885-4895, https://doi.org/10.5194/bg-9-4885-2012, 2012.

Wang, D., Hamm, L. M., Bodnar, R. J., and Dove, P. M.: Raman spectroscopic characterization of the magnesium content in amorphous calcium carbonates, J. Raman Spectrosc., 43, 543548, 2012.

Watson, E. B.: A conceptual model for near-surface kinetic controls on the trace-element and stable isotope composition of abiogenic calcite crystals, Geochim. Cosmochim. Ac., 68, 14731488, 2004.

Wehrmeister, U., Soldati, A. L., Jacob, D. E., Häger, T., and Hofmeister, W.: Raman spectroscopy of synthetic, geological and biological vaterite: a Raman spectroscopic study, J. Raman Spectrosc., 41, 193-201, https://doi.org/10.1002/jrs.2438, 2009.

Weisstein, E.: Gaussian Function, available at: http://mathworld. wolfram.com/GaussianFunction.html (last access: November 2017), 2017.

White, W.: The carbonate minerals, in: The Infra-red Spectra of minerals, edited by: Farmer, V., 227-284, Mineralogical Society, London, 1974.

Wu, H. C., Dissard, D., Le Cornec, F., Thil, F., Tribollet, A., Moya, A., and Douville, E.: Primary Life Stage Boron Isotope and Trace Elements Incorporation in Aposymbiotic Acropora millepora Coral under Ocean Acidification and Warming, Front. Mar Sci., 4, 129, https://doi.org/10.3389/fmars.2017.00129, 2017.

Zakaria, F. Z., Mihály, J., Sajó, I., Katona, R., Hajba, L., Aziz, F. A., and Mink, J.: FT-Raman and FTIR spectroscopic characterization of biogenic carbonates from Philippine venus seashell and Porites sp. coral, J. Raman Spectrosc., 39, 1204-1209, https://doi.org/10.1002/jrs.1964, 2008.

Zeebe, R. E., Ridgwell, A., and Zachos, J. C.: Anthropogenic carbon release rate unprecedented during the past 66 million years, Nature Geoscience, 9, 325-329, https://doi.org/10.1038/ngeo2681, 2016. 